\title{
Assessing France's Joint Audit Requirement: Are Two Heads Better than One?*
}

\author{
by \\ Jere R. Francis \\ University of Missouri-Columbia \\ and \\ Chrystelle Richard \\ Université Paris Dauphine \\ and \\ Ann Vanstraelen \\ Universiteit Antwerpen and Universiteit Maastricht
}

Draft Date: November 2006

*We appreciate the comments of Jean Bédard, Bob Roussey, Hervé Stolowy, workshop participants at Institut d'Aministration d'Entreprises in Paris, Université Paris Dauphine, and participants at the 2006 International Symposium on Audit Research in Sydney, Australia, and the 2006 EIASM Workshop on Audit Quality in Milan, Italy.

Contact Author:

Jere R. Francis

University of Missouri-Columbia

Voice: +01573 8825156

FAX: +015738822437

Email: francis@missouri.edu 


\title{
Assessing France's Joint Audit Requirement: Are Two Heads Better than One?
}

\begin{abstract}
We examine auditor choice for listed companies in France where two (joint) auditors are required by law. The joint audit requirement creates a unique setting to study if a firm's ownership structure affects its auditor-pair choice as well the consequences on earning quality. The results support predictions from agency theory that higher quality (Big 4) auditors are more likely to be used as external monitors when there is greater separation of ownership and control and increased information asymmetry between the firm and outsiders. A Big 4 auditor (paired with a non-Big 4 auditor) is more likely to be used for firms with more diversified ownership structures and less family blockholdings, and these associations are even stronger for firms with two Big 4 auditors conducting the joint audit. We also test if a firm's auditor-pair choice affects earnings quality and find that firms using one Big 4 auditor (paired with a non-Big 4 auditor) have smaller income-increasing abnormal accruals compared to firms that use no Big 4 auditors, and once again this effect is even stronger for firms that use two Big 4 auditors. While French firms do have more concentrated ownership structures than Anglo-America firms, we conclude that cross-sectional differences in ownership structures create economic incentives that affect auditor-pair choices under France's joint auditor requirement, and that earnings are of high quality when audited by Big 4 auditors. Finally, we report evidence that French audit fees are no higher under a joint audit approach compared to other European countries. While we do not know if the joint audit approach necessarily produces a better quality audit than the singleauditor approach used in most countries, we do find that French firms are valued more highly than neighboring firms in Belgium, which has a similar legal and regulatory system, and this finding suggests investors may perceive two heads (auditors) are better than one in reducing information uncertainty with respect to reported earnings.
\end{abstract}




\section{Assessing France's Joint Audit Requirement: Are Two Heads Better than One?}

\section{Introduction}

All publicly-listed companies in France that prepare consolidated (group) financial statements are required to be jointly audited by two independent auditors, with the audit effort shared and a single audit report issued by the two auditors of record. To our knowledge, this corporate governance requirement is unique to France and Denmark, and we use this institutional setting to assess if a firm's choice of auditors in France is a function of ownership structure and agency costs. The fact that two auditors must be jointly selected makes the auditor choice decision more complex than in other countries, with the possibility of more gradations in audit quality than the typical Big 4/non-Big 4 dichotomy that has been studied in other countries. Another unique feature of the French data is the ability to test ownership structure characteristics in far greater detail than is possible with US data. In particular, ownership data is reported for eight separate categories of investors in France as well as the largest individual shareholders. In addition to the analysis of ownership structure and auditor choice, we also examine the consequences of a firm's auditor-pair choice on the quality of its reported earnings with respect to abnormal accruals.

DeAngelo (1981) argues that accounting firm size is a proxy for audit quality, and a large body of Anglo-American research documents that audits by the large international (now Big 4) accounting firms are more expensive and of higher quality than audits of smaller accounting firms (Francis 2004; Watkins et al. 2004). While the international Big 4 firms are the largest accounting firms in France in terms of overall revenues there are many French accounting firms, both small and large, involved in the audits of public companies (Parthenay 2004). In our sample of listed companies only $11.5 \%$ use two Big 4 auditors; thus, the majority of French 
companies are audited by at least one non-Big 4 auditor. Applying DeAngelo’s (1981) sizequality framework to France, the highest quality audit should occur when both auditors are one of the international Big 4 firms, and the lowest quality when both auditors are small (French) accounting firms. Audits performed by one Big 4 auditor (paired with a non-Big 4 accounting firm) and by large French accounting firms would fall in between these two extremes.

The primary research question in our study is whether higher quality auditing occurs in France when there is information asymmetry arising from the separation of ownership and control (e.g., Jensen and Meckling 1976; Watts and Zimmerman 1983); and, secondly, whether auditor choice has an observable effect on the quality of reported earnings. It is not self-evident what the answers are to either of these two research questions. ${ }^{1}$ France has a civil law legal system which is generally viewed as having lower investor protection compared to AngloAmerican countries like the UK and the US, and which results in more concentrated ownership structures because of the inability of firms to fully overcome information asymmetry between the firm and external (minority) investors (La Porta et al. 1998). In addition, bank financing plays a relatively more important role in civil law countries, resulting in more of an "insider” ownership and financing structure compared to common law countries (Leuz et al. 2003). The upshot is that it is far from obvious there is a demand for differential audit quality in France based on the firm's ownership structure and agency costs. Further, given the relative absence of auditor litigation in France (Piot and Janin 2005), it is also unclear if accounting firms themselves have incentives to supply differential audit quality, and studies of other European countries with civil law legal systems generally find little evidence to support the existence of differential audit

\footnotetext{
${ }^{1}$ For example, while agency theory predicts less information asymmetry with higher insider ownership and therefore less demand for high quality external monitoring, Piot (2001) finds no evidence that auditor choice in France is related to the level of insider ownership held by directors, manager and employees.
} 
quality (e.g., Vanstraelen 2002; Vander Bauwhede et al. 2003; Vander Bauwhede and Willekens 2004; Maijoor and Vanstraelen 2006).

What do we find? As predicted by agency theory, there is evidence that cross-sectional differences in ownership structure affect auditor choice in France even though ownership structures are more concentrated than in Anglo-American countries. Specifically, as a firm's ownership structure in France becomes less concentrated and has greater ownership by investors other than family owners, the firm is more likely to have a Big 4 auditor as one or both auditors. In addition, two Big 4 auditors are more likely to be used than one Big 4 auditor (paired with a non-Big 4 auditor) as international and institutional ownership increases, and when the firm's ownership structure is less dominated by family blockholdings. There is also weak evidence of differentiation between large and small French accounting firms.

We also examine if the auditor-pair choice affects the quality of a company's reported earnings, and find that companies with one or two Big 4 auditors are less likely to have incomeincreasing abnormal accruals than other firms. This is consistent with U.S. findings that Big 4 auditors constrain aggressive earnings management (Becker et al. 1998; Francis et al. 1999). Firms audited by two Big 4 accounting firms are even less likely to have income-increasing accruals compared to firms audited by just one Big 4 auditor paired with a non-Big 4 auditor. In terms of the question posed by the paper's title, it would seem that having two Big 4 auditors is better than one in terms of earnings quality in France, but we find no evidence that French investors value companies more highly if audited by Big 4 firms. Finally, we document that audit fees of French companies are no larger than fees of other European countries. Although our study cannot determine if joint audits per se produce better quality audits in France than would otherwise occur with a single-auditor approach, we do provide evidence that French 
companies are valued more highly than companies in neighboring Belgium which has a similar legal and regulatory environment. This finding is at least suggestive that the joint audit approach in France reduces information uncertainty with respect to reported earnings and results in higher market valuations, ceteris paribus.

The remainder of the paper is organized as follows. Section 2 discusses the joint audit requirement in France and provides institutional detail about the French audit market. The sample and descriptive statistics are reported in section 3. The auditor choice tests are presented in section 4, and section 5 reports the earnings quality tests. Stock market valuation effects of auditor-pair choices are reported in section 6, and section 7 reports the analysis of audit fees in France versus other European countries. Section 8 summarizes and concludes the study.

\section{Auditing in France}

The audit market in France is serviced by the international Big 4 audit firms, two other large American-based international firms (BDO and Grant Thornton), a few large French firms and numerous small French accounting firms. The 10 largest firms in France based on 20032004 revenues are in descending order: KPMG, Ernst \& Young, PricewaterhouseCoopers, Deloitte, Mazars, Salustro Reydel (absorbed in 2004 by KPMG), BDO Marque et Gendrot, Grant Thornton, Secafi Alpha, and Scacchi \& Associés (Parthenay 2004). The large French firms in our study are defined as the four French firms in the top 10 (i.e., Mazars, Salustro Reydel, Secafi Alpha, and Scacchi \& Associés) plus the $11^{\text {th }}$ largest firm in France, Constantin. ${ }^{2}$ Despite the dominance by Big 4 firms in overall revenues, only $11.5 \%$ of companies in our sample (n=54) are audited by two Big 4 auditors, which means that most listed companies in France have either one or two French accounting firms as their auditors.

\footnotetext{
${ }^{2}$ We include Constantin as large French audit firm because their revenues in 2003-2004 are just below Scacchi \& Associés. Furthermore, Constantin was ranked number nine in terms of revenues in 2002-2003 and is considered a big French player in the audit market.
} 
The regulation of auditing in France is summarized in the Appendix. For our study, the most important requirement is a joint audit for listed public companies and for other private entities which are required to report consolidated financial statements. This means that the audit report is signed by two auditors from different audit firms, which are jointly liable for the issued opinion. The joint audit requirement for listed companies has been in force since 1966, although it was already a common practice at the time it was formally adopted. Bennecib (2004) suggests the historical emergence of a joint audit is explained by two rationales. First, it can be used as a measure to deal with the problem of default by one of the auditors. A defaulting auditor can only be replaced upon a decision of the Court of Commerce, which can result in a delay of the availability of the annual report, which companies may not want to incur. Second, a joint audit can safeguard auditor independence which would give the French auditing profession greater credibility and prestige.

In 1984, the joint audit requirement was put into doubt by the introduction of consolidated financial reporting at the European level ( $7^{\text {th }}$ EU Directive, 1983). Prior to 1984, group accounts were not required, and the policy debate in France centered on whether or not to make a joint audit mandatory for companies that must consolidate under the new EU regulation or leave it as a voluntary choice. The final decision in 1984 extended the requirement of a mandatory joint audit to companies required to prepare consolidated financial statements. Bennecib (2004) believes this decision was influenced by the changing structure of the French audit market at that time. In particular, it appeared in the 1980s that the presence of AngloAmerican audit firms was significantly increasing, precisely because of the newly introduced EU consolidation requirement. Anglo-American accounting firms already had the necessary expertise for group accounting, while French firms lagged behind in their expertise in this area. 
Hence, Anglo-American audit firms gained substantial market share. As a result of this increased competition, French audit firms put pressure on the French National Assembly to keep and extend the joint audit requirement because they feared that most, if not, all large French companies would ultimately be audited by large Anglo-American accounting firms.

Piot and Janin (2005) argue that the joint audit is now "perceived to have two advantages: (1) to offer a reciprocal check of each auditor's diligence; and (2) to reinforce each auditor's independence.” Article 105 of the French Financial Security Law (2003) states that the audit firms have to divide their work following the requirements of the professional standards. In practice, it can be argued that the effectiveness of a joint audit depends to a large extent on the comparable allocation of effort between the two auditors (Piot and Janin 2005). However, based on a study by Le Maux (2004), it appears that audit fees paid to dual auditors are far from equal as there are statistically significant differences between fees paid to the two auditors. As a result Le Maux (2004) questions the effectiveness of joint audits and suggests it may be little more than a fool's game. However, Noël (2005) demonstrates that the differences in audit fees can be attributed largely to differences in perceived reputation of auditors. In particular, the difference in audit fees when joint auditors are of a different type (e.g., a Big 4 firm and a small French audit firm) is on average 57\%, while the difference in audit fees between joint auditors of the same type of audit firms (e.g., two Big 4 audit firms or two small French audit firms) is on average only 25\%. Noël (2005) concludes that in the majority of the cases, the second auditor does not act as a "subordinate" auditor, but rather as a legitimate counterweight which offers a concomitant view on the fairness of the financial statements. In addition, the French Financial Security Law (2003) now formally requires the joint auditors to perform a cross-review of their respective work. 


\section{Sample and Descriptive Statistics}

The sample consists of all French listed companies registered in 2003 on the French Market Authority's website (www.amf-france.org). The French Market Authority's website contains the annual reports of these firms including information on a company's joint auditors. In 2003 a total of 604 companies were registered of which 136 companies did not file an annual report, resulting in a final sample of 468 companies. ${ }^{3}$ The DIANE database (June 2005 version) was used to determine ownership data for the study. ${ }^{4}$ An important feature of the database is the classification of shareholdings by eight different investor groups that allows us to investigate the effect of cross-sectional differences in ownership structure on auditor choice in greater detail than is possible with US ownership data (e.g., Francis and Wilson 1988; DeFond 1992).

The joint auditor choices are summarized in Table 1. A total of 54 companies $(11.5 \%$ of sample) use two Big 4 auditors, and the remaining 414 companies have at least one French auditor. Of these 414 companies, 241 (51.5\% of the sample) use one Big 4 auditor paired with a non-Big 4 auditor. Thus 295 companies (63\%) in the sample use at least one Big 4 auditor, while the remaining 173 observations (37\%) use no Big 4 auditors. Of the 173 observations with no Big 4 auditor, 104 companies use two small French auditors (22\% of sample), and 62 observations (13\% of the sample) are audited by either two large French auditors or a large French auditor coupled with another non-Big 4 auditor (only four companies use two large French auditors). Finally, seven observations are audited by BDO or Grant Thornton coupled with a small French accounting firm.

\footnotetext{
${ }^{3}$ Not filing the annual report at the French Market Authority results in a small fine for the company, but it appears that some companies prefer the fine rather than filing their annual report.

4 The DIANE database is a product of Bureau Van Dijk Electronic Publishing. Bureau Van Dijk distributes international databases like OSIRIS and AMADEUS, and national databases like DIANE. It contains financial data and ownership data for listed and non-listed firms in France. DIANE does not provide historical data on ownership, and the reported ownership data refers only to the most recent year in the database. Given that we do not have prior versions of the DIANE database, we only examine one year in the study.
} 
In sum, while the Big 4 are dominant in France in terms of overall revenues, other accounting firms are well-represented in the audit market, more so than is the case in the United States where the Big 4 firms now audit approximately $90 \%$ of publicly-listed companies. In contrast, only $11.5 \%$ of the French listed companies in our sample use two Big 4 auditors. Thus if one purpose of the joint audit requirement was to protect the French audit market from domination by non-French firms when the consolidated reporting requirement was introduced in 1984, then one could argue that the policy has been quite effective in contrast to the Big 4's domination of the U.S. audit market.

\section{[Insert Table 1 Here]}

Descriptive statistics on ownership variables and other variables used in the analysis are reported in Table 2. Ownership structure is measured in three different ways: a dichotomous variable if the largest single shareholder owns $25 \%$ or more of shares; the specific ownership percentages held by each of eight different investor groups; and an indicator variable denoting which of these eight investor groups has the largest share ownership in a company. These three ownership variables are now explained in greater detail.

\section{[Insert Table 2 Here]}

The dichotomous variable "Concentration" is coded zero if a single shareholder owns $25 \%$ or more, and is coded one otherwise. The DIANE database reports this dichotomous variable rather than the actual percentage owned by the single largest investor. This variable identifies those firms with low versus high ownership concentration based on the holding by the single largest shareholder. A higher quality audit is expected when there is low ownership concentration due to greater information asymmetry (i.e., more diverse investors with smaller holdings), while a lower quality audit is expected when there is high concentration as these 
stockholders can engage in direct monitoring and control of the firm. As expected, French firms do have concentrated ownership structures. The single largest investor owns $25 \%$ or more of shares for the majority of firms (73\%) in the study. This is a much higher level of concentration than the U.S. where the three largest institutional investors hold an average of only $14 \%$ of the shares of U.S. firms, and where the sum of shareholdings for all investors with $5 \%$ ownership (or more) averages only 35\%. ${ }^{5}$ Given the high level of ownership concentration in France relative to the U.S., it is unclear if cross-sectional differences in French ownership structures are of sufficient importance to matter in terms of agency costs, information asymmetry or the demand for differential audit quality (Piot 2001).

The next eight variables in Table 2 report the average ownership percentages in the sample for each of eight separate ownership categories reported in the DIANE database. The largest ownership is direct investment by other companies (denoted Industry_own\%) which averages 33.652\% of shares; the second largest category is family ownership (Family_own\%) with $25.087 \%$ of shares; and the third largest group is general public ownership (Pub_own\%) with $20.779 \%$ of shares. International investors (Intl_own\%) hold $8.504 \%$ of shares and banks own $4.750 \%$. The remaining three ownership groups (state, employees, and pension funds) are quite small and collectively own only $4.25 \%$ of shares. We initially thought that state, employee and pension fund ownership might be an important feature of ownership structure in French companies; however, it is clear that the state has largely divested its ownership of French listed companies, and the shareholdings are quite small for the other two groups as well. Overall these ownership percentages are consistent with French companies having the kind of concentrated ownership structures (including family ownership) that are typical outside Anglo-American

\footnotetext{
${ }^{5}$ These percentages are based on averages in fiscal 2003 for $n=7,366$ U.S. firms with $5 \%$ ownership data from Compact Disclosure, and n=6,693 U.S. firms with institutional ownership data from Thomson Financial.
} 
countries (Morck 2005). In particular family holdings average $26 \%$ for the sample compared to U.S. family blockholdings of only 7.4\% for S\&P 500 firms in the same period (Wang 2006).

The third ownership variable is based on which one of the eight ownership groups has the largest shareholding percentage in a company, and the appropriate indicator variable is coded one. The largest share ownership is held by other companies (Industry_maj) for $42.9 \%$ of the sample; public investors (Public_maj) hold the largest share ownership for 27.5\% of the sample; and families (Family_maj) own the largest block of shares for 23.5\% of the sample. Banks are the majority investor (Bank_maj) for 2.9\% of the sample, and pension funds (Pensfund_maj) for $1.9 \%$ of the sample. Only $1 \%$ of the sample has the largest ownership block held by the state or by employees, and none of the companies in the sample has international investors as the largest ownership group.

Table 2 shows the sample distribution across industry sectors based on 1-digit SIC codes, and $37.8 \%$ of the sample is in the financial sector (SIC code 6). The accruals variables used to test earnings quality are discussed in more detail later in the paper, but means are as follows: total accruals (TACC) average -0.018 of lagged total assets; current accruals (CACC) average 0.003 of lagged total assets; and signed abnormal working capital accruals are -0.007 of lagged total assets (AWCACC). The three accruals variables are used in the tests of earnings quality and are based on a smaller number of observations due to data requirements. In addition we reduce the effect of outliers by removing the top and bottom $2.5 \%$ of the distributions of each of the accruals variables.

The control variables are also reported in Table 2. Company size (Ln(Assets)) has a mean (median) value of 11.372 (10.986) which equates to 1.6 billion Euros (median is 58 million Euros); company profitability (ROA) has a median value of $2.7 \%$ and mean of $-0.3 \%$; company 
growth (Growth Assets) is the one-year percentage increase in total assets and has a mean value of $8.45 \%$ (median is $1.71 \%$ ); complexity (Complex) is measured by the turnover ratio (sales divided by lagged assets) and has a mean value of 0.659; and debt (Leverage) averages of 28.4\% of total assets. None of the control variables is unduly correlated with the ownership variables or accruals variables as the highest pair-wise correlation is only 0.215 .

\section{Auditor Choice Tests}

The auditor choice tests are reported in Table 3 based on the following logistic (logit) regression model:

$$
\text { Auditor-Pair Choice }=\mathrm{f} \text { (ownership structure, control variables) }
$$

The auditor choice dependent variable is based on a series of dichotomous partitions of auditor size categories as defined below, with larger auditors coded one and smaller auditors coded zero. DeAngelo (1981) argues that accounting firm size is a proxy for audit quality because larger firms have more quasi-rents at risk if a negligent audit is performed and larger firms are also better able to withstand client reporting pressures since a single client is less important as the firm's total clientele increases. A large body of empirical research mainly from Anglo-American countries supports the argument that the large international accounting firms provide qualitydifferentiated audits (Francis 2004; Watkins et al. 2004). Based on this research, the choice of two international Big 4 auditors is assumed to denote the highest level of audit quality; the second highest quality is the use of one Big 4 auditor paired with a non-Big 4 auditor; the third highest quality is the use of one or two large French accounting firms; and the lowest quality is the use of two small French accounting firms. However, we re-emphasize that it is a priori unknown if the auditor size-quality linkage holds in France due to institutional differences in France relative to Anglo-American countries. For this reason, our study is a joint test of the size- 
quality linkage in France, as well as a test of the effects of ownership structure on auditor choice. As in other auditor choice research, all auditors in France, irrespective of size, are all assumed to meet the minimum level of audit quality required by regulatory and professional standards.

As discussed above, ownership structure is specified and tested in three different ways: (1) a single dichotomous variable (Concentration) coded 1 for low concentration by the single largest shareholder $(<25 \%)$ and coded 0 for high concentration (25\% or more); (2) a set of variables specifying the ownership percentages held by each of eight classes of investors (international, general public, the state, banks, employees, industry (other companies), pension funds, and families); and (3) a set of indicator variables indicating which one of seven ownership classes has the largest ownership percentage in a company. ${ }^{6}$ The three specifications of ownership structure are reported in Table 3 in column (1), column (2), and column (3), respectively.

The set of control variables is based on prior auditor choice studies and controls for the effect of auditee size (Ln(Assets)), profitability (ROA), growth (Growth Assets), leverage (Leverage) and organizational complexity (Complexity) measured as asset turnover ratio (sales divided by assets). Prior research shows that the larger accounting firms are more likely to be chosen for large and/or growing companies, profitable companies that are better able to pay higher fees, more complex companies, and companies with higher debt levels (Francis and Wilson 1988; DeFond 1992; Anderson et al. 1993; Chaney et al. 2004).

The logit models used to test the auditor choice model in equation (1) are reported in Table 3. Four auditor partitions are reported in Panels A through D, with three separate models per auditor partition using the three specifications of ownership structure. Panel A compares

\footnotetext{
${ }^{6}$ International investors are not the largest shareholder group for any observations in the sample; hence, this variable is not included in this analysis, which results in seven ownership classes instead of eight.
} 
firms using two Big 4 auditors with firms using all other auditor pairs in order to determine if ownership structure is associated with the putatively highest quality audit (two Big 4 firms). The next two panels decompose the primary analysis in Panel $\mathrm{A}$ as follows. In Panel $\mathrm{B}$, a comparison is made of firms using two Big 4 auditors versus firms using just one Big 4 auditor (paired with a non-Big 4 auditor) to test if there is differential demand for two Big 4 auditors rather than one Big 4 as a function of ownership structure. Panel C then compares firms using one Big 4 auditor (paired with a non-Big 4 auditor) with firms using two non-Big 4 auditors and tests if there is differential demand for one Big 4 auditor as a function of ownership structure. Finally, Panel D examines firms using non-Big 4 auditor pairs and compares firms using a large versus small French accounting firms.

With respect to the ownership structure variables, we expect companies to choose a higher quality auditor (based on various specifications of auditor size) when there is less concentrated ownership by the largest single shareholder (Concentration=1) which means that the ownership structure is more diverse, resulting in greater information asymmetry between the firm and owners. In terms of the ownership percentages by different equity groups, higher quality auditing is expected for increasing levels of international ownership and public ownership because these investors face the greatest information asymmetry relative to other investor groups that may, to some degree, have a closer relationship with the company. Companies with significant family ownership are least likely to have information asymmetry problems because there is less separation of ownership and control and therefore such firms have less need for higher quality external auditors. Institutional investors (pension funds and banks) have a fiduciary responsibility to their own shareholders and are expected to demand higher quality monitoring through the use of larger accounting firms. We make no specific predictions 
on how ownership levels by other companies (industry), the state, or employees will affect auditor choice. Each of these investor groups has potentially closer knowledge of the company relative to other investor groups in which case there may be less need for a higher quality external audit; alternatively, if these groups have a large ownership block they may demand higher quality monitoring in order to protect their investment. For simplicity, one-tail p-values are reported on all ownership variables, even though no directional prediction is made for ownership levels by other companies (industry), the state, or employees.

[Insert Table 3 Here]

All models in Panels A, B and C in Table 3 are significant at $\mathrm{p}<.01$, while in Panel D, two of the three models are significant at $\mathrm{p}<.05$. The only insignificant model in Table 3 is the model reported in column (1) of Panel D. All individual coefficients are tested using asymptotic t-statistics, and the corresponding z-values are one-tail probabilities for the ownership variables of interest, and two-tail probabilities for all other variables. With respect to the control variables in the model estimations in Table 3, the only consistently significant variable across all estimations is that larger accounting firms are more likely to be used by larger companies. There is some evidence that companies with higher leverage levels are more likely to use larger accounting firms (Panel B), and that more complex companies use larger accounting firms (Panel C). Unexpectedly, growth companies are less likely to use larger accounting firms (Panel C), but this result is driven by smaller companies with high growth rates and which use mainly smaller French auditors.

The analysis in Panel A of Table 3 compares companies choosing two Big 4 auditors ( $n=54)$ with all other companies $(n=414)$ in the sample. The results provide strong support for agency theory. In column (1), the use of two Big 4 auditors is more likely when there is low 
ownership concentration (Concentration=1). In column (2), two Big 4 auditors are more likely with higher levels of international ownership, public ownership, and institutional ownership (banks and pension funds). ${ }^{7}$ In contrast, two Big 4 auditors are less likely as family blockholding increases. There is no statistical association for increasing levels of ownership by industry (other companies), the state, or employees. These results are consistent with our expectations based on information asymmetry and agency costs. International owners and public investors will be most familiar with the international Big 4 accounting firms and therefore will have more confidence in audits performed by these firms compared to less well known French accounting firms. When family ownership is high, the need for a high quality external monitor is low. There is less information asymmetry arising from separation of ownership and control because families are likely to be closely involved in company management. With respect to bank and pension fund ownership, institutional investors have fiduciary responsibilities to their own investors and therefore demand higher quality external monitoring in those companies in which they invest. Finally, in column (3) the use of two Big 4 auditors is higher in all cases relative to the default comparison group of companies in which families are the largest ownership group. Thus the positive coefficients on the other ownership variables reflect that for all of these firms, there is greater likelihood of two Big 4 auditors compared to those firms in which families are the largest blockholder. Again this makes sense because information asymmetry and agency costs are lowest for companies in which there is majority family ownership and, by implication, agency costs are greater for all other ownership structures. In sum, the evidence is strongly supportive

\footnotetext{
${ }^{7}$ The model in column (2) is estimated as follows for all of the panels in Table 3. Reported results for the control variables are based on a single model estimation in which all eight of the ownership variables are jointly included in the model. However, there is structural correlation among the eight ownership variables since by definition they sum to $100 \%$ of a firm's ownership. Therefore, to avoid structural correlation and serious multicollinearity problems, the model in column (2) is estimated using each ownership variable one at a time (along with the set of control variables), and the reported statistical results for each of the ownership variables are based on this approach.
} 
that agency costs arising from ownership structure increase the use of higher quality external auditors in France through the use of two international Big 4 accounting firms.

The next partition is reported in Panel B and compares 54 companies using two Big 4 firms with 241 companies using one Big 4 firm plus a non-Big 4 auditor to satisfy the joint audit requirement. The purpose of this test is to clarify the analysis in Panel A by examining if ownership structure affects the use of two Big 4 auditors rather than just one Big 4 auditor (paired with a non-Big 4 firm). The results in Panel B are broadly similar to those in Panel A and indicate those particular circumstances in which two Big 4 auditors are more likely to be used than just one Big 4 auditor. In column (1), the ownership concentration variable "Concentration" is not statistically significant. However, in column (2), the use of two Big 4 auditors rather than one is more likely to occur as international ownership increases, and as institutional ownership increases (banks and pension funds); and the use of two Big 4 auditors is less likely as family ownership increases. The results in column (3) with respect to the largest ownership group also parallel those in Panel A. Two Big 4 auditors are more likely to be used when all ownership groups are dominant relative to family ownership, except for public and state ownership although these two variables are close to statistical significance at the .10 level. We conclude that agency costs of ownership structures with greater information asymmetry results in the use of two rather one Big 4 auditor as an external monitor.

The third auditor partition is reported in Panel $\mathrm{C}$ of Table 3 and compares companies choosing one Big 4 auditor paired with a non-Big 4 auditor $(n=241)$ versus companies with no Big 4 auditors (n=173). Firms having one Big 4 auditor are coded one to denote a higher quality audit than firms choosing two non-Big 4 auditors. The results in Panel $\mathrm{C}$ again provide support for agency arguments with respect to ownership structure. In column (1), the use of one Big 4 
auditor is more likely when there is low ownership concentration (Concentration=1), and in column (2) the use of a Big 4 auditor is significantly positively associated with increasing levels of public ownership, and increasing levels of international ownership and employee ownership. Ownership by other companies (industry) is weakly and negatively associated with the use of one Big 4 auditor (note that no directional relation was specified). Again these results are consistent with our expectations based on information asymmetry. General public investors and international investors are more distanced from the company in which case there would be a greater need for a credible audit when these investor groups hold large ownership percentages. Employees may also demand higher quality audits when their stake in a company is higher. In column (3), firms in which the general public is the largest ownership group are more likely to have a Big 4 auditor relative to the default group of family dominated firms. The other ownership variables are insignificant in column (3) except for pension funds which has an unexpected negative sign indicating less use of a Big 4 auditor relative to firms in which a family is the largest blockholder. We have no explanation for this result, although it should be interpreted with care since the number of firms with pension funds as majority owner is very small ( $n=7)$ compared to the number of firms in which families are the largest ownership group ( $\mathrm{n}=106)$. In sum, the evidence indicates that one Big 4 auditor is preferred to "none” as an external monitor based on the firm’s ownership structure and resultant information asymmetry.

The final partition in Panel $\mathrm{D}$ of Table 3 is an analysis of companies using French accounting firms. Specially, we compare 62 companies using one or two large French firms (recall that only four companies in our sample use two large French firms) with 104 companies using two small French firms. Again, assuming that larger French accounting firms are of higher quality than smaller French firms, the use of at least one large French firm is assumed to 
represent a choice of higher quality auditing relative to those companies choosing two small French firms as the auditor pair. These estimations are reported in Panel D of Table 3. The only significant results for ownership variables are in column (2) in which larger ownership percentages by industry (other companies) and pension funds are associated with greater use of a large French accounting firm; and in column (3) where a large French accounting firm is more likely to occur (relative to family-dominated firms) when public investors, industry investors, banks or pension funds are the major ownership group. Overall the evidence in Panel D is weaker than the other auditor partitions, but does provide evidence that ownership structure affects the use of large rather than small French accounting firms, at least in some circumstances.

In sum, the auditor choice tests in our study are unique in terms of a more complex ordering of audit quality in France than in other countries due to the joint audit requirement and therefore the range of auditor pairs that are observed. Overall, we find evidence consistent with predictions from agency theory: higher quality auditing is associated with ownership structures in which there is increasing separation of ownership and control and more information asymmetry between the investor group and the firm. In particular, the use of Big 4 auditors increases when the ownership structure is less concentrated by a single large blockholder, and has more international and public investors; while the use of Big 4 auditors is less likely when there is large family ownership. In addition, a Big 4 auditor is more likely as institutional ownership (banks and pension funds) increases. Importantly, there is evidence that some of these ownership characteristics are also associated with the use of two rather than one Big 4 auditor, which suggests that two Big 4 auditors are perceived to be better than one as an external monitor. With respect to French accounting firms, there is some evidence that larger French accounting firms are more likely to be used than two small French firms when there is less family ownership 
and when a larger ownership percentage is held either by other companies or by pension funds. We conjecture that the demand for higher quality auditing by corporate investors is due to a larger investment at risk, and in the case of institutional investors a fiduciary responsibility to their own investors.

Thus agency explanations for auditor choice are borne out despite the fact that France is a civil law country where traditional agency theory might not necessarily be applicable due to different institutional structures. Civil law countries are different from common law countries in terms of weaker investor protection and its effect on agency problems, which in turn affects the financing and ownership structure of firms (La Porta et al. 1998). As a result, there is more concentrated ownership relative to U.S. companies, and larger ownership by groups such as families that have a close relationship with the company (Thomsen, Pedersen and Kvist 2006; Roosenboom and Schramade 2006; Maury 2006; Morck 2005; Grier and Zychowicz 1994). Despite these institutional differences, and their effects on ownership structure, our evidence indicates that agency theory explains the demand for higher quality audits in France as a function of the separation of ownership and control and increasing information asymmetry between the firm and owners.

\section{Earnings Quality Tests}

Earnings quality is evaluated by comparing the accrual component of earnings for companies with different auditor-pair combinations in the following OLS regression model:

Accruals $=\mathrm{f}$ (auditor-pair choice, control variables, industry indicator variables)

The same four partitions of auditors are used as in Table 3. Control variables are based on prior studies and include size (Ln(Assets)), debt levels (Leverage), and profitability (ROA). Prior studies find that accruals are greater for large firms (even after scaling accruals for firm size), 
and firms with high debt levels or low profitability have been argued to have greater incentives to aggressively manage accruals in order to avoid debt default and to avoid reporting losses (Becker et al. 1998). General industry effects on accruals are controlled through industry indicator variables based on one-digit SIC codes.

Accruals map to earnings quality in the following manner. There is evidence in the research literature that accrual-based earnings are more value-relevant and informative to investors than operating cash flows (Dechow 1994). However, there is also evidence that a dollar of the accrual component of earnings has a lower association with the market valuation of firms than a dollar of operating cash flows (e.g., Subramanyam 1996). This finding is consistent with the fact that accruals are the product of estimations and judgments by managers about future events (Dechow and Dichev 2002). In addition, because the implementation of accrual accounting necessarily involves these estimations and judgments, it is possible for managers to use their discretion to deliberately distort accrual-based earnings for personal reasons such as meeting earnings targets in order to earn bonus plan compensation, or meeting analysts' earnings forecasts in order to sustain company stock prices and therefore ensure job security as well increasing the value of unexercised managerial stock options.

The typical approach in analyzing accruals is to undertake a cross-sectional comparison of accruals for a sample of companies from a common fiscal year. All things being equal, earnings with relatively larger amounts of accruals are presumed to be inherently less reliable and more likely to be the result of opportunistic discretion by managers in applying accrualbased accounting. Therefore larger accruals imply lower earnings quality, ceteris paribus. In our study we use the following cross-sectional measures of accruals for the 2003 fiscal year: (1) the absolute value of total accruals (TACC) defined as: (change in current assets - change in cash 
and cash equivalents) - (change in current liabilities - change in short-term debt and current portion of long-term debt) - depreciation and amortization, scaled by lagged total assets (Dechow et al., 1995); (2) the absolute value of current accruals (CACC) scaled by lagged assets, where current accruals are defined as: (change in current assets - change in cash and cash equivalents) - (change in current liabilities - change in short-term debt and current portion of long-term debt); and (3) the absolute value of abnormal current or working capital accruals (AWCACC) scaled by lagged assets, defined as the absolute value of actual current accruals minus expected (predicted) current accruals. Expected accruals are based on a linear model in DeFond and Park (2001) in which the prior year's ratio of current accruals to sales is applied to next-period sales to predict next-period accruals. Since earnings quality is impaired if earnings are either overstated or understated in a particular period, the absolute value of abnormal accruals are used to assess earnings quality (Warfield and Wild 1995).

In addition, abnormal working capital accruals are analyzed separately for observations with income-increasing (positive) accruals and income-decreasing (negative) accruals. The reason for this additional analysis is the widely held view that the use of aggressive accounting practices to increase earnings is more problematic for earnings quality than the discretionary use of accruals to reduce current period earnings.

A cross-sectional Jones (1991) model is not used to estimate abnormal accruals because it requires more data than the approach in DeFond and Park (2001) and would cause a large reduction in the number of observations. In our sample, if two-digit SIC codes are used to define industry categories, as is typically the case, then only 11 of 37 industries have the rule-of-thumb 10 minimum observations required to estimate the Jones model. ${ }^{8}$ In addition, a recent study

\footnotetext{
${ }^{8}$ In addition, Piot and Janin (2005) use the Jones (1991) model to estimate abnormal accruals for a sample of 102 French firms, and find no association between accruals and auditor choice, although they have a less complete
} 
suggests that the Jones model does not perform well on non-U.S. data, and this may be in part caused by small industry samples in international settings (Meuwissen et al. 2005).

Results of the OLS regression models of the earnings quality tests are reported in Table 4. The sample size is reduced relative to Table 3 for two reasons. First observations in the financial services sector are dropped because the accrual structure is qualitatively different for firms in the financial sector. Second observations with extreme values for the accruals variables (top and bottom $2.5 \%$ of the distributions) are also dropped. Individual coefficients are tested using tstatistics. One-tail p-values are reported for the experimental auditor variables and two-tail values for all other variables. The absolute values of total accruals, current accruals, and abnormal working capital accruals are not statistically significant in any of the models reported in Table 4. However, as discussed below, there is evidence of a systematic association between accruals and auditor choice when abnormal working capital accruals are partitioned into firms with income-increasing (positive) abnormal accruals and firms with income-decreasing (negative) abnormal accruals.

\section{[Insert Table 4]}

The first auditor partition in Panel A compares companies with two Big 4 auditors with all other companies in the sample. There is evidence that firms with two Big 4 auditors are less likely to have income-increasing abnormal working capital accruals (AWCACC). The t-statistic of -1.47 is significant with a one-tail p-value of .07 , and the negative sign indicates that higher quality auditing through the use of two Big 4 auditors is associated with smaller incomeincreasing accruals. None of the other accrual variables is significant in Panel A. However, the fact that total accruals and current accruals are not significant in any of the tests in Table 4 gives

analysis of auditor-pairs than in our study as they only compare firms using a Big 4 auditor (either one or two) with firms using non-Big 4 auditors. 
confidence that the statistical results for abnormal accruals are not driven by differences in the overall magnitude of accruals, per se.

The partition reported in Panel B of Table 4 compares firms using two Big 4 auditors with firms using only one Big 4 auditor, and the results are similar to Panel A. The use of higher quality auditing (two Big 4 firms) is associated with smaller income-increasing abnormal working capital accruals relative to firms using just one Big 4 auditor paired with a non-Big auditor. The t-statistic is -1.48 and is significant with a one-tail p-value of 0.07 . This analysis shows that two Big 4 auditors are a more effective external monitor than one Big 4 auditor (paired with a non-Big 4 firm) in constraining income-increasing abnormal accruals. As in Panel A, none of the other accruals variables is significant.

Panel C of Table 4 reports the results of companies using one Big 4 auditor paired with a non-Big 4 auditor, versus those companies using two non-Big 4 auditors. These results are comparable to Panels A and B and show that the use of higher quality auditing (in this case one Big 4 auditor versus no Big 4 auditors) is associated with smaller income-increasing abnormal working capital accruals. The t-statistic is -1.54 and is significant with a one-tail p-value of .06. As in Panel A, none of the other accruals variables is significant.

Finally, Panel D of Table 4 reports the partition comparing the use of one (or two) large French accounting firms with companies that use two small French accounting firms. Only one of the accruals variables is significant: companies using large French accounting firms have smaller income-decreasing abnormal working capital accruals than do companies using two small French accounting firms as their auditors (t-statistic is 2.10 and is significant with a onetail p-value of .05). This suggests earnings are less likely to be managed downwards when audited by large French accounting firms. An explanation is that small French accounting firms 
may allow their clients more discretion to reduce reported earnings in order to minimize taxation. Prior research shows that earnings are managed downward for tax-related incentives (Shackelford and Shevlin, 2001).

In sum, the evidence in Table 4 in Panels A, B, and C consistently indicates that clients of Big 4 auditors have smaller income-increasing abnormal working capital accruals, and that the earnings of these companies are therefore of higher quality because they are less likely to be affected by opportunistic managerial discretion that overstates earnings. The evidence also indicates that earnings quality is highest when two Big 4 auditors are used, and next highest when one Big 4 auditor is used. The results in Panel D for French accounting firms provide evidence of a greater constraint on income-decreasing earnings management by companies with large French auditors than for companies with small French auditors. Taken together, the results in Tables 3 and 4 tell a consistent story. Companies with greater agency costs due to increasing separation of ownership and control and greater information asymmetry are more likely to be audited by (larger) higher quality accounting firms, and the earnings of these companies appear to be of higher quality based on the analysis of abnormal working capital accruals. The implied pecking order of audit quality is two Big 4 auditors, one Big 4 auditor (paired with a non-Big 4 auditor), large French auditors, and small French auditors.

\section{Market Valuation Analysis}

\subsection{Auditor Effects on the French Stock Market}

The next analysis examines if investors in the French stock market value companies differently as a function of their auditor-pair choices. We adapt models in La Porta et al. (2002) and Doidge et al. (2004), and measure valuation differences using price-to-book (PB) ratios and controlling for the effects of firm size, leverage and growth on PB ratios. The PB ratio is a proxy 
for Tobin's q which is widely used in the finance literature to measure the valuation effects of alternative governance structures. In addition we test for differences in price-to-earnings (PE) ratios because the PE ratio is a widely used valuation metric in the investment community. If earnings are viewed as being of higher quality when audited by Big 4 auditors, then firms should trade at higher price multiples for a given level of earnings or book value of equity (which includes the cumulative past earnings of the firm). Results of the valuation tests are reported in Table 5 for 339 observations with PB ratios and 324 observations with PE ratios. The mean (median) PB ratio is 2.04 (1.45) and mean (median) PE ratio is 10.14 (10.9). Note that the results in Table 5 are unaffected when adding one-digit industry codes as an additional control for industry effects.

\section{[Insert Table 5 Here]}

Table 5 parallels the format in Table 4 and reports four separate auditor-pair analyses in which a higher quality auditor-pair is contrasted with a lower quality auditor-pair. Panel A compares firms with two Big 4 auditors with all other auditor-pairs; Panel B compares firms with two Big 4 auditors with firms having only one Big 4 auditor (paired with a non-Big 4 auditor); Panel C compares firms with one Big 4 auditor with firms having no Big 4 auditors; and Panel D compares firms with one (or two) large French auditors with firms having small French auditors.

There is no evidence in Table 5 that any of the PB ratios or PE ratios are significantly affected by auditor-pair choices. We conclude there is at least the possibility that the stock market does not correctly understand the earnings/accruals quality implications of auditor-choice pairings in France. In addition, given the evidence in Table 4 that reported earnings are systematically lower for firms with Big 4 auditors, due to smaller income-increasing abnormal accruals, this means that earnings (and book values) are reported more conservatively for firms 
with Big 4 auditors. It follows that these firms should trade at larger price multiples for a given level of earnings and book value, all things being equal. It appears that the stock market is fixated on the level of reported earnings and does not take differential earnings or accruals quality into consideration (Hand 1990; Sloan 1996).

\subsection{Are Two Heads Better than One? A Comparison of France and Belgium}

If the French joint audit system reduces information risk and leads to more credible earnings, it follows that the market valuation of earnings should be higher relative to firms in other countries using a single-auditor approach, ceteris paribus. We provide some initial evidence on this important policy question by comparing PB and PE ratios of French firms (which have two auditors) and Belgian firms (which use one auditor). Belgium was part of France until the mid- $19^{\text {th }}$ century, and its civil law legal system and corporate practices are broadly similar to those in France, although a recent World Bank study indicates that Belgium has stronger protection of investors. On a 10-point scale, the investor protection score is 7 in Belgium and only 5.3 in France. ${ }^{9}$ A study of international property rights prepared by the Heritage Foundation (http://www.heritage.org) also indicates that Belgium has stronger legal protection than France. On a five-point scale Belgium scores 1 which is the strongest protection while France has a score of 2. To the extent that Belgium may have a stronger corporate governance and investor protection environment, our analysis is biased against finding any positive market effect from the French joint audit requirement.

We follow the same approach as in Table 5 and regress a firm’s PB and PE ratios on the following explanatory variables: an indicator variable coded one for French firms, plus control variables for firm size (log of assets), leverage (debt to total assets), and firm growth (sales

\footnotetext{
${ }^{9}$ The investor protection score is based on the average of three separate indices for disclosure quality, directors' liability, and the ability of shareholders to bring lawsuits. Information on the World Bank data and methodology can be found at the website, http://www.doingbusiness.org/ExploreTopics/ProtectingInvestors/.
} 
growth percentage over the prior year), a set of industry variables for one-digit industry classifications, and a set of indicator variables for fiscal year since the data comes from French and Belgian companies in the Worldscope database for the three-year period 2003 to 2005. Firm-year observations are excluded if a PB ratio or PE ratio is less than zero. For the PB ratio, there are 2,330 firm-year observations from France (777 unique firms) and 358 firm-year observations from Belgium (120 unique firms). PB ratios have median value of 1.64 in France and 1.36 in Belgium. PE ratios are based on a slightly smaller sample of 2080 firm-year observations from France and 360 observations from Belgium, and have a median value of 12.51 in France and 11.77 in Belgium.

The regressions indicate that French companies have significantly larger PB ratios, with an average increase in $\mathrm{PB}$ ratios of 0.21 (t-statistic is $1.76, \mathrm{p}=.04$, one-tail). The results are stronger if the log of PB ratio is used to linearize the ratio (t-statistic is $1.92, \mathrm{p}=.03$, one-tail). French companies also have significantly larger PE ratios. Using PE ratio and log of PE ratio, the t-statistic on the French indicator variables is 3.8 and is significant at $\mathrm{p}<.01$.

It is possible other important firm fundamentals are omitted from the model and that these would explain the higher PB and PE ratios for French companies. However, at face value our analysis indicates there are higher price multiples for French firms that are subject to the joint audit requirement, which suggests that two auditors for French companies may be perceived by investors as superior to the one-auditor approach used by Belgian companies in terms of reducing the information risk with respect to reported earnings.

\section{Effects on Audit Fees}

To recap, our study finds that French firms with ownership structures that have greater information asymmetry between insiders and outsiders are more likely to use two Big 4 auditors 
to fulfill the joint audit requirement in France. We also document that French firms jointly audited by two Big 4 auditors have smaller income-increasing abnormal accruals, which is evidence of higher earnings quality. Thus in terms of the question posed by the paper's title, there is evidence that two Big 4 auditors are better than one, and that one Big 4 auditor is better than none, although there is no evidence that firms are valued more highly in the French stock market if they have Big 4 auditors. However, a comparison of French and Belgian firms indicates that French firms have higher PB and PE ratios, which provides some evidence the use of two auditors (France) may be more effective in reducing information risk and leading to higher market valuations than occurs with the conventional single-auditor approach used in Belgium (and most other countries).

The final issue examined is whether the French joint audit system is more costly than the single-auditor approach. Such an analysis is important in evaluating the cost-effectiveness of France's joint audit requirement as a possible guide for other countries. We provide some preliminary evidence on this question using data for a sample of 100 European firms with Big 4 auditors that cross-list in the United States and which report audit fees under U.S. reporting requirements. The data are obtained from Audit Analytics for the period 2000 through 2005. Specifically we compare the fees of 31 French companies ( $\mathrm{n}=116$ firm-year observations), with the fees of 71 other companies (n=246 firm-year observations) from Belgium, Italy, Luxemburg, Netherlands, and Germany. ${ }^{10}$ These six countries have similar civil law legal traditions and are the original founding members of the European Union.

\footnotetext{
${ }^{10}$ The sample consists of the following observations: France $n=116$ (31 unique firms); Belgium $n=12$ ( 3 unique firms), Luxembourg n=19 (5 unique firms); Netherlands $n=113$ (32 unique firms); Germany $n=74$ (21 unique firms); and Italy $\mathrm{n}=28$ ( 8 unique firms). Total sample is $\mathrm{n}=362$ firm-year observations from the period 2000 to 2005, and $\mathrm{n}=100$ unique firms.
} 
The fee model is restricted to data available in Audit Analytics and we regress log of audit fees on the following set of explanatory variables: log of sales, log of assets, yearly indicator variables for the years 2000 to 2004 (default is 2005), and a test variable which is coded one if the firm-year observation is a French company. The model is estimated using OLS with robust t-statistics corrected for serial dependence since there are multiple years of observations for some firms. The model has good explanatory power with an adjusted r-square of 0.8748 , and sales and assets are both positively associated with audit fees at $p<.01$. The test variable has an insignificant coefficient $(\mathrm{p}=.61)$, indicating that audit fees for French firms are not statistically different from the fees of non-French firms in the sample. Thus the French joint audit requirement does not appear to cause higher fees, at least for firms that cross-list in the U.S.

\section{Discussion and Conclusion}

This study investigates a unique corporate governance requirement in France in which two auditors jointly undertake audits and issue a jointly signed audit report. This makes a firm’s choice of auditors more complex than the usual case around the world in which a single auditor is engaged. Our study examines if a firm's ownership structure is associated with its choice of joint auditors: specifically, do agency costs arising from the separation of ownership and control lead to the use of a higher quality auditor pair as an external monitor?

Drawing on prior Anglo-American research, the implied hierarchy of audit quality in France is: (1) the use of two Big 4 auditors; (2) the use of one Big 4 auditor paired with a nonBig 4 auditor; (3) the use of large French accounting firms; and (4) the use of two small French accounting firms. The tests support the existence of this four-level hierarchy of audit quality, but such an outcome was not obvious. France is a civil law country in which ownership structures are more concentrated with large shareholdings by families and less general public ownership 
than is the case in Anglo-American countries. Given this institutional structure, there may not be serious information asymmetry problems in which case there is not necessarily a demand for differential audit quality. In addition, there may be no incentives for accounting firms to supply differential audit quality in France due to the relative absence of litigation and regulatory sanctions that could adversely affect an accounting firm's reputation if they perform bad audits.

Nevertheless, it turns out that agency theory is strongly supported in our study of French listed companies. Larger and putatively higher quality auditors are more likely to be used when there is less concentrated ownership, greater public and international ownership, and less inside ownership by families. These findings are quite strong and in some ways surprising. The reason for the surprise is that the theoretical linkage between ownership structure and auditor choice is very strong in Anglo-American countries, yet the empirical evidence from the US can be characterized as very weak at best (e.g., Francis and Wilson 1988; DeFond 1992). In contrast, we document a very strong association in France where agency costs do appear to matter and to affect auditor choice, despite the fact that French firms have much higher ownership concentration than U.S. firms.

We also examine the consequence of auditor choice on earnings quality. Given the relative absence of litigation and other auditor sanctions, it is unclear if there is the same incentive in France for auditors to protect their brand name reputation by providing high quality audits, and prior European studies have been unable to replicate US research on differential earnings quality for clients of Big 4 auditors. We find that French companies audited by a Big 4 auditor are less likely to have income-increasing abnormal accruals, and that companies with two Big 4 auditors are even less likely to have such accruals. Despite this evidence of higher 
earnings quality, the French stock market does not appear to value the earnings of firms more highly if they are audited by Big 4 auditors.

In sum, the evidence indicates that the complexity of auditor choice in France created by the joint audit requirement plays out in a way consistent with underlying economic incentives from agency costs driving the use of Big 4 auditors and resulting in higher quality financial reporting. We also find that audit fees of French companies are not significantly different from the fees of non-French companies that cross-list in the U.S., so the preliminary evidence indicates that the joint audit system is not necessarily costlier than a single-auditor approach. Even though two Big 4 auditors appear to be better than one Big 4 auditor (paired with a non-Big 4 firm), and one Big 4 auditor appears to be better than none, as a caveat we acknowledge that we do not know if the joint audit requirement in France is more effective and produces better quality audits than the single-auditor approach used in most other countries. However, we do find that French firms are valued more highly than Belgian firms, which is suggestive that earnings are valued more highly under the joint audit regime, in which case the stock market may perceive that two heads are better than one. Given this preliminary evidence, additional research is warranted to further examine if joint audits are superior to the traditional singleauditor approach in most countries. 


\section{Appendix}

\section{Audit Regulation in France}

The statutory audit of companies in France is governed by Company Law (Loi sur les Sociétés Commerciales of 24 July 1966). Following the $4^{\text {th }}$ EU Directive, companies that meet specific legal form and/or size criteria are required to have their financial statements audited by a member of the regulatory body of the French auditing profession, which is the French National Institute of Auditors (Compagnie Nationale des Commissaires aux Comptes, CNCC). The CNCC is under supervision of the Ministry of Justice. All public companies and incorporated partnerships (sociétés en commandite par actions) are required to be audited irrespective of their size. In addition, private limited liability companies, limited partnerships (sociétés en commandite simple) and general partnerships (sociétés en nom collectif) are subject to the auditing requirement if they exceed two of the following three size criteria at balance sheet date: (1) total assets of 1,550,000 euros; (2) sales, excluding tax, of 3,100,000 euros; (3) 50 or more employees.

Auditors in France are appointed for a period of six years. The auditor cannot be dismissed during this six-year period except under exceptional circumstances that require a court decision. Resignation of the auditor during this period is likewise restricted. The audit firm's appointment can be renewed without limitation for further six-year periods, although for listed firms a mandatory audit partner rotation was introduced in 2003 by the French Financial Security Law. The auditor certifies that the financial statements give "a true and fair view of the company's result for the year and of the state of affairs at the year end" (Article 228, Commercial Code). Besides reporting on "truth and fairness" the statutory auditor (Commissaire aux Comptes) must also report on compliance with company law, criminal acts or fraud, that 
have a material impact on the financial statements, and going concern. The audit has to be conducted in accordance with the generally accepted auditing standards and guidelines promulgated by the French National Institute of Auditors (CNCC). The CNCC issues standards and guidelines on auditing matters and is assisted in this respect by the Regional Institutes of Statutory Auditors (Compagnies Régionales des Commissaires aux Comptes) (Buijink et al. 1996). The statutory auditors are appointed at the annual general meeting of shareholders.

In response to financial scandals in the U.S. and Europe, the Code of Commerce was modified in 2003 by the French Financial Security Law. This law created a new High Council of Auditors to provide supervision of the profession with support of the CNCC and to ensure respect for professional ethics and the independence of auditors (Baker et al., 2006). Furthermore, the French Financial Security Law (2003) established the French Financial Market Authority (Autorité des Marchés Financiers, AMF) to oversee the functioning of the securities market. The AMF must be informed of proposals to appoint or reappoint auditors of listed companies, may request information on listed client companies from auditors and are entitled to inspect an auditor of a listed company and to request assistance of the CNCC (Baker et al., 2006). The French Financial Security Law (2003) also created a new internal control reporting requirement for the auditor. In particular, auditors need to give an opinion on the chairman of the Board of Directors' report describing the internal control procedures relating to the origination and processing of the accounting and financial information (Baker et al., 2006). Auditors also have new reporting obligations under the French Financial Security Law (2003), and are required to raise with the AMF audit client issues which are likely to impact financial reporting, under a waiver of client confidentiality. In particular, auditors must inform the AMF on matters where 
the auditors refuse to certify the accounts, and auditors must immediately report information in cases of going concern problems and discovered irregularities or inaccuracies.

The auditor's report and the financial statements have to be filed with the Companies Registry within one month following their approval at the annual general meeting, followed by an announcement of the filing of these documents in the legal gazette (BODACC), and are publicly available (Gélard 2001). The client company, its shareholders, or any interested third party can undertake legal action against an auditor. France has adopted a proportional liability system, placing liability upon the defendants according to their contribution to damages (Buijink et al. 1996). Legal liability cannot be capped by law or by contract, and auditors in France are required to maintain a minimum professional indemnity insurance of 75,000 euros. Legal action against a statutory auditor can only be undertaken within three years after the issue of the auditor's report, although compared with the U.S., litigation rates in France are quite low (Piot and Janin 2005).

Even though legal liability exposure does not create the same incentive for high quality auditing in France as in the U.S., relative to other EU countries France does have strict regulations to safeguard auditor independence (Maijoor and Vanstraelen 2006). As mentioned, there is a minimum length of the audit mandate of six years, listed firms that prepare consolidated financial statements are required to have a joint audit, and the appointment of the statutory auditor needs to be approved by the French Financial Market Authority (Autorité des Marchés Financiers, AMF). Furthermore, independence regulations in France prohibit the provision of management advisory services and advertising, and there are also restrictions on auditors moving to clients or client personnel moving to audit firms. Statutory auditors are subject to reviews by peers and regulators. These regulations have been in place many years 
before the EU issued its recommendation on auditor independence regulations in May 2002. Since the implementation of the EU recommendation on independence regulations in 2005, listed companies in France are also required to have an audit committee. 


\section{References}

Anderson, D., D. Stokes and I. Zimmer. 1993. Corporate takeovers and auditor switching. Auditing: A Journal of Practice and Theory (12): 65-73.

Baker, C.R., J. Bédard, and C. Prat di Hauret. 2006. Auditing in France. Working Paper.

Becker, C., M. DeFond, M. Jiambalvo, and K.R. Subramanyam. 1998. The effect of audit quality on earnings management. Contemporary Accounting Research (Spring): 1-24.

Bennecib, F. 2004. Le co-commissariat aux comptes: sa contribution à l'accroissement de l'indépendance de l'auditeur. Doctoral Dissertation. Université Paris Dauphine, 350 pages.

Buijink, W., S. Maijoor, R. Meuwissen, and A. van Witteloostuijn. 1996. The Role, Position, and Liability of the Statutory Auditor within the European Union. Study commissioned by DG XV of the European Commission, Luxembourg: ECSC-EC-EAEC.

Chaney, P., D. Jeter, and L. Shivakumar. 2004. Self-selection of auditors and audit pricing in private firms. The Accounting Review (79): 51-72.

DeAngelo, L. 1981. Auditor size and audit quality. Journal of Accounting and Economics (3): 183-199.

Dechow, P. 1994. Accounting earnings and cash flows as measures of firm performance: the role of accounting accruals. Journal of Accounting and Economics (18): 3-42.

Dechow, P., and I. Dichev. 2002. The quality of accruals and earnings: the role of accrual estimation errors. The Accounting Review (77 Supplement): 35-59.

Dechow, P., R. Sloan, and A. Sweeney. 1995. Detecting earnings management. The Accounting Review (70): 193-225.

DeFond, M. 1992. The association between changes in client firm agency costs and auditor switching. Auditing: A Journal of Practice and Theory (11):16-31.

DeFond, M.L., and C. Park. "The reversal of abnormal accruals and the market valuation of earnings surprises.” The Accounting Review 76 (July 2001): 375-404.

Doidge, C., G. Karolyi, and R. Stulz. 2004. Why are foreign firms listed in the U.S. worth more? Journal of Financial Economics (71): 205-238.

Francis, J. 2004. What do we know about audit quality? The British Accounting Review (36): 345-368. 
Francis, J., E. Maydew, and H.C. Sparks. 1999. The role of big 6 auditors in the credible reporting of accruals. Auditing: A Journal of Practice and Theory (18): 17-34.

Francis, J. and D. Simon. 1988. The effects of auditor change on audit fees: tests of price cutting and price recovery. The Accounting Review (63): 255-269.

Francis, J., and E. Wilson. 1988. Auditor changes: a joint test of theories relating to agency costs and auditor differentiation. The Accounting Review (63): 663-682.

Gélard, G. 2001. “France”, in Transnational Accounting, edited by Ordelheide, D., $2^{\text {nd }}$ edition, Palgrave, Houndmills.

Grier, P. and E. Zychowicz. 1994. Institutional investors, corporate discipline, and the role of debt. Journal of Economics \& Business (46):1-11.

Hand, J. 1990. A test of the extended functional fixation hypothesis. The Accounting Review (65): 740-763.

Jensen, M., and W. Meckling. 1976. Theory of the firms: managerial behavior, agency costs, and ownership structure. Journal of Financial Economics (October): 305-360.

Jones, J. 1991. Earnings management during import relief investigations. Journal of Accounting Research (Autumn): 193-228.

LaPorta, R., F. Lopez-de-Silanes, A. Schleifer and R. Vishny. 1998. Law and finance. Journal of Political Economy (106): 1113-1155.

LaPorta, R., F. Lopez-de-Silanes, A. Schleifer and R. Vishny. 2002. Investor protection and corporate valuation. Journal of Finance (57): 1147-1170.

Leuz, C., D. Nanda and P. Wysocki. 2003. Earnings management and investor protection: An International Comparison. Journal of Financial Economics (69): 505-527.

Le Maux, J. 2004. Le co-commissariat aux comptes à la française. Revue Française de la Comptabilité (May): 34-38.

Maijoor, S. and A. Vanstraelen. 2006. Earnings management within Europe: The effects of member state audit environment, audit firm quality and international capital markets”, Accounting and Business Research (36): 33-52.

Maury, B. 2006. Family ownership and firm performance: Empirical evidence from Western European corporations. Journal of Corporate Finance (12): 321-341. 
Meuwissen, R., F. Moers, E. Peek, and A. Vanstraelen. "An evaluation of abnormal accruals measurement models in an international context.” Working Paper, 2005. University of Maastricht and University of Antwerp, available on the Social Science Research Network at: http://papers.ssrn.com/sol3/papers.cfm?abstract_id=442681.

Morck, R. (editor). 2005. A History of Corporate Governance Around the World. Chicago: University of Chicago Press.

Noël, C. 2005. Le co-commissariat aux comptes à la française : Réponse aux doutes soulevés par Julien Le Maux. Revue Française de la Comptabilité (April): 26-29.

Parthenay, M.L. 2004. La profession comptable libérale en France - Etude 2004 : les cabinets de plus de 7Meuros de CA. Revue La Profession Comptable (254).

Piot, C. 2001. Agency costs and audit quality : Evidence from France. The European Accounting Review (10): 461-499.

Piot, C. and R. Janin. 2005. Audit quality and earnings management in France. Working Paper, available on SSRN.

Roosenboom, P. and W. Schramade (2006). The price of power: Valuing the controlling position of owner-managers in French IPO firms. Journal of Corporate Finance (12): 270-295.

Shackelford, D.A. and T. Shevlin. 2001. Empirical tax research in accounting. Journal of Accounting and Economics (31): 321-387.

Sloan, R. 1996. Do stock prices fully reflect information in accruals and cash flows about future earnings? The Accounting Review (71): 289-315.

Subramanyam, K.R. 1996. The pricing of discretionary accruals. Journal of Accounting and Economics 22 (August-December): 249-291.

Thomsen, S., T. Pedersen and H. Kvist. 2006. Blockholder ownership: Effects on firm value in market and control based governance systems. Journal of Corporate Finance (12): 246269.

Vander Bauwhede, H., M. Willekens and A. Gaeremynck. 2003. Audit Quality, Public Ownership and Firms' Discretionary Accruals Management. International Journal of Accounting (38): 1-22.

Vander Bauwhede, H. and M. Willekens. 2004. Evidence on (the Lack of) Audit-Quality Differentiation in the Private Client Segment of the Belgian Audit Market. European Accounting Review (13): 501-522. 
Vanstraelen, A. 2002. Auditor economic incentives and going-concern opinions in a limited litigious continental European business environment: empirical evidence from Belgium. Accounting and Business Research (32): 171-186

Warfield, T., J. Wild, and K. Wild. 1995. Managerial ownership, accounting choices, and informativeness of earnings. Journal of Accounting and Economics (20): 61-91.

Watkins, A., W. Hillison, S. Morecroft. 2005. Audit quality: a synthesis of theory and empirical evidence. Journal of Accounting Literature (23): 153-193

Watts, R., and J. Zimmerman. 1983. Agency problems, auditing, and the theory of the firm: some evidence. Journal of Law and Economics (26): 613-634. 
Table 1

Number of observations per audit-pair combinations

\begin{tabular}{|l|l|l|}
\hline Auditor Pairs & Number of observations & Frequency \\
\hline Two Big 4 auditors & 54 & $11.5 \%$ \\
\hline $\begin{array}{l}\text { A Big 4 auditor paired with a } \\
\text { non-Big 4 auditor }\end{array}$ & 241 & $51.5 \%$ \\
\hline $\begin{array}{l}\text { Two large French auditors, or } \\
\text { one large French auditor } \\
\text { paired with a small French } \\
\text { auditor* }\end{array}$ & 62 & $13.3 \%$ \\
\hline $\begin{array}{l}\text { BDO or Grant Thornton, } \\
\text { paired with a small French } \\
\text { auditor }\end{array}$ & 7 & $1.5 \%$ \\
\hline Two small French auditors & 104 & $22.2 \%$ \\
\hline Total & 468 & $100 \%$ \\
\hline
\end{tabular}

*Only four observations use two large French accounting firms which is why we combine the two groups. The firms classified as "large" French firms are the ones ranked in the top 10 plus the $11^{\text {th }}$ largest firm in France in terms of revenues (Parthenay 2004): Mazars, Salustro Reydel, Secafi Alpha, Scacchi \& Associés, and Constantin. 
Complex: Sales/Lagged total assets

Ln(Assets): Natural log of total assets

Leverage: Total debt/Total assets

ROA: Return on assets

Growth assets: Percentage change in total assets

Growth sales: Percentage change in sales

SIC 10: Dummy variable for US SIC Code 10-19

SIC 20: Dummy variable for US SIC Code 20-29

SIC 30: Dummy variable for US SIC Code 30-39

SIC 40: Dummy variable for US SIC Code 40-49

SIC 50: Dummy variable for US SIC Code 50-59

SIC 60: Dummy variable for US SIC Code 60-69

SIC 70: Dummy variable for US SIC Code 70-79

SIC 80: Dummy variable for US SIC Code 80-89

TACC: Total accruals, scaled by lagged total assets

CACC: Current accruals, scaled by lagged total assets

AWCACC: Abnormal working capital accruals, scaled by total assets

Note: For the three accruals variables TACC, CACC, and AWCACC there are fewer observations to due data availability. In addition, extreme values (the top and bottom $2.5 \%$ of distributions) are eliminated for each of the variables. 
Table 3

Logistic regression model of auditor-pair choices

Panel A: Two Big 4 auditors $(n=54)$ versus all other auditor pairs $(n=414)$

\begin{tabular}{|c|c|c|c|}
\hline & $\begin{array}{l}\text { Column (1) } \\
\text { Coefficient (z-value) }\end{array}$ & \begin{tabular}{|l|} 
Column (2) \\
Coefficient (z-value)
\end{tabular} & $\begin{array}{l}\text { Column (3) } \\
\text { Coefficient (z-value) }\end{array}$ \\
\hline Constant & $\begin{array}{l}-5.359 \\
(-6.15)^{* * *}\end{array}$ & $\begin{array}{l}-3.465 \\
(-2.94)^{* * *}\end{array}$ & $\begin{array}{l}-6.01 \\
(-6.11)^{* * *}\end{array}$ \\
\hline Complex & $\begin{array}{l}-0.169 \\
(-0.77)\end{array}$ & $\begin{array}{l}-0.173 \\
(-0.78)\end{array}$ & $\begin{array}{l}-0.193 \\
(-0.89)\end{array}$ \\
\hline Ln(Assets) & $\begin{array}{l}0.246 \\
(3.87)^{* * *}\end{array}$ & $\begin{array}{l}0.169 \\
(2.46)^{* *}\end{array}$ & \begin{tabular}{|l|}
0.227 \\
$(3.42)^{* * *}$
\end{tabular} \\
\hline Leverage & $\begin{array}{l}0.850 \\
(1.38)\end{array}$ & $\begin{array}{l}0.770 \\
(1.20)\end{array}$ & $\begin{array}{l}1.010 \\
(1.63)\end{array}$ \\
\hline Growth assets & $\begin{array}{l}-0.0001 \\
(-0.05) \\
\end{array}$ & $\begin{array}{l}-0.000 \\
(-0.01)\end{array}$ & $\begin{array}{l}-0.000 \\
(-0.00)\end{array}$ \\
\hline ROA & $\begin{array}{l}1.497 \\
(1.27)\end{array}$ & $\begin{array}{l}1.260 \\
(1.04)\end{array}$ & $\begin{array}{l}1.149 \\
(0.97)\end{array}$ \\
\hline Concentration & $\begin{array}{l}0.608 \\
(1.95)^{*}\end{array}$ & & \\
\hline Intl_own\% & & $\begin{array}{l}0.017 \\
(2.45)^{* * *}\end{array}$ & \\
\hline Pub_own\% & & $\begin{array}{l}0.017 \\
(2.70)^{* * *}\end{array}$ & \\
\hline State_own\% & & $\begin{array}{l}0.028 \\
(1.13)\end{array}$ & \\
\hline Bank_own\% & & $\begin{array}{l}0.022 \\
(2.19)^{* *}\end{array}$ & \\
\hline Empl_own\% & & \begin{tabular}{|l|}
0.009 \\
$(0.21)$ \\
\end{tabular} & \\
\hline Industry_own\% & & $\begin{array}{l}-0.004 \\
(-0.79)\end{array}$ & \\
\hline Pensfund_own\% & & $\begin{array}{l}0.017 \\
(1.66)^{* *}\end{array}$ & \\
\hline Family_own\% & & $\begin{array}{l}-0.026 \\
(-3.21)^{* * *}\end{array}$ & \\
\hline Pub_maj & & & $\begin{array}{l}1.203 \\
(2.07)^{* *}\end{array}$ \\
\hline Industry_maj & & & $\begin{array}{l}1.126 \\
(2.00)^{* *} \\
\end{array}$ \\
\hline Pensfund_maj & & & $\begin{array}{l}2.022 \\
(2.06)^{* *}\end{array}$ \\
\hline Bank_maj & & & $\begin{array}{l}1.953 \\
(2.32)^{* *}\end{array}$ \\
\hline State_maj & & & $\begin{array}{l}2.167 \\
(1.82)^{* *}\end{array}$ \\
\hline Empl_maj & & & n.a. (no observations) \\
\hline Family_maj & & & Default group \\
\hline Pseudo R ${ }^{2}$ & $8.02 \%$ & $15.6 \%$ & $9.81 \%$ \\
\hline$\chi^{2}$ & $26.83^{* * *}$ & $52.22^{* * *}$ & $32.82^{* * *}$ \\
\hline
\end{tabular}

${ }^{*} \mathrm{p}<.10,{ }^{* *} \mathrm{p}<.05,{ }^{* * *} \mathrm{p}<.01$ (2-tailed and 1-tailed for ownership variables). Note that column (2) ownership percentages in Table 3 are based on models estimated with each ownership variable one at a time along with control variables, rather than a joint estimation. 
Table 3 Continued

Panel B: Two Big 4 auditors $(n=54)$ versus one Big 4 auditor paired with a non-Big 4 auditor $(\mathbf{n}=\mathbf{2 4 1})$

\begin{tabular}{|c|c|c|c|}
\hline & $\begin{array}{l}\text { Column (1) } \\
\text { Coefficient (z-value) }\end{array}$ & \begin{tabular}{|l|} 
Column (2) \\
Coefficient (z-value)
\end{tabular} & $\begin{array}{l}\text { Column (3) } \\
\text { Coefficient (z-value) }\end{array}$ \\
\hline Constant & $\begin{array}{l}-4.119 \\
(-4.48)^{* * *}\end{array}$ & $\begin{array}{l}-2.799 \\
(-2.16)^{* *}\end{array}$ & $\begin{array}{l}-5.103 \\
(-4.81)^{* * *}\end{array}$ \\
\hline Complex & $\begin{array}{l}-0.269 \\
(-1.10)\end{array}$ & \begin{tabular}{|l|}
-0.236 \\
$(-1.04)$ \\
\end{tabular} & \begin{tabular}{|l|}
-0.265 \\
$(-1.11)$ \\
\end{tabular} \\
\hline Ln(Assets) & $\begin{array}{l}0.189 \\
(2.83)^{* * *}\end{array}$ & $\begin{array}{l}0.156 \\
(2.08)^{* *}\end{array}$ & $\begin{array}{l}1.382 \\
(2.10)^{* * *}\end{array}$ \\
\hline Leverage & $\begin{array}{l}1.143 \\
(1.76)^{*}\end{array}$ & $\begin{array}{l}1.085 \\
(1.58)\end{array}$ & $\begin{array}{l}1.382 \\
(2.10)^{* *}\end{array}$ \\
\hline Growth assets & $\begin{array}{l}0.001 \\
(0.58) \\
\end{array}$ & $\begin{array}{l}0.002 \\
(0.66)\end{array}$ & $\begin{array}{l}0.001 \\
(0.60)\end{array}$ \\
\hline ROA & $\begin{array}{l}1.536 \\
(1.26)\end{array}$ & $\begin{array}{l}1.388 \\
(1.08)\end{array}$ & $\begin{array}{l}1.382 \\
(1.06)\end{array}$ \\
\hline Concentration & $\begin{array}{l}0.313 \\
(0.96)\end{array}$ & & \\
\hline Intl_own\% & & $\begin{array}{l}0.015 \\
(2.01)^{* *}\end{array}$ & \\
\hline Pub_own\% & & $\begin{array}{l}0.009 \\
(1.36)^{*}\end{array}$ & \\
\hline State_own\% & & $\begin{array}{l}0.019 \\
(0.78)\end{array}$ & \\
\hline Bank_own\% & & $\begin{array}{l}0.025 \\
(2.17)^{* *}\end{array}$ & \\
\hline Empl_own\% & & $\begin{array}{l}-0.009 \\
(-0.20) \\
\end{array}$ & \\
\hline Industry_own\% & & $\begin{array}{l}-0.0023 \\
(-0.44)\end{array}$ & \\
\hline Pensfund_own\% & & $\begin{array}{l}0.045 \\
(2.68)^{* * *}\end{array}$ & \\
\hline Family_own\% & & $\begin{array}{l}-0.025 \\
(-3.00)^{* * *}\end{array}$ & \\
\hline Pub_maj & & & $\begin{array}{l}0.786 \\
(1.31)^{*}\end{array}$ \\
\hline Industry_maj & & & $\begin{array}{l}1.077 \\
(1.87)^{* *}\end{array}$ \\
\hline Pensfund_maj & & & $\begin{array}{l}3.797 \\
(2.73)^{* * *}\end{array}$ \\
\hline Bank_maj & & & $\begin{array}{l}1.775 \\
(1.97)^{* *}\end{array}$ \\
\hline State_maj & & & $\begin{array}{l}1.612 \\
(1.35)^{*} \\
\end{array}$ \\
\hline Empl_maj & & & n.a. (no observations) \\
\hline Family_maj & & & Default group \\
\hline Pseudo $\mathrm{R}^{2}$ & $6.26 \%$ & $14.16 \%$ & $9.98 \%$ \\
\hline$\chi^{2}$ & $17.59^{* * *}$ & $39.78^{* * *}$ & $28.00^{* * *}$ \\
\hline
\end{tabular}

${ }^{*} \mathrm{p}<.10,{ }^{* *} \mathrm{p}<.05,{ }^{* * *} \mathrm{p}<.01$ (2-tailed and 1-tailed for ownership variables). 
Table 3 Continued

Panel C: One Big 4 auditor paired with a non-Big 4 auditor $(n=241)$ versus all others using two non-Big 4 auditors $(n=173)$

\begin{tabular}{|c|c|c|c|}
\hline & \begin{tabular}{|l|} 
Column (1) \\
Coefficient (z-value)
\end{tabular} & $\begin{array}{l}\text { Column (2) } \\
\text { Coefficient (z-value) }\end{array}$ & $\begin{array}{l}\text { Column (3) } \\
\text { Coefficient (z-value) }\end{array}$ \\
\hline Constant & $\begin{array}{l}-1.735 \\
(-2.69)^{* * *}\end{array}$ & $\begin{array}{l}-1.096 \\
(-1.30)\end{array}$ & $\begin{array}{l}-1.525 \\
(-2.32)^{* *}\end{array}$ \\
\hline Complex & $\begin{array}{l}0.239 \\
(1.92)^{*}\end{array}$ & $\begin{array}{l}0.221 \\
(1.77)^{*}\end{array}$ & $\begin{array}{l}0.218 \\
(1.70)^{*}\end{array}$ \\
\hline Ln(Assets) & $\begin{array}{l}0.170 \\
(3.21)^{* * *}\end{array}$ & \begin{tabular}{|l|}
0.137 \\
$(2.47)^{* *}$
\end{tabular} & $\begin{array}{l}0.152 \\
(2.78)^{* * *}\end{array}$ \\
\hline Leverage & $\begin{array}{l}-0.529 \\
(-1.21)\end{array}$ & $\begin{array}{l}-0.663 \\
(-1.49)\end{array}$ & $\begin{array}{l}-0.619 \\
(-1.40)\end{array}$ \\
\hline Growth assets & $\begin{array}{l}-0.003 \\
(-1.65)\end{array}$ & $\begin{array}{l}-0.003 \\
(-1.76)^{*}\end{array}$ & $\begin{array}{l}-0.003 \\
(-1.79)^{*}\end{array}$ \\
\hline ROA & \begin{tabular}{|l|}
0.174 \\
$(0.42)$
\end{tabular} & $\begin{array}{l}0.190 \\
(0.42)\end{array}$ & $\begin{array}{l}0.192 \\
(0.46)\end{array}$ \\
\hline Concentration & $\begin{array}{l}0.800 \\
(3.17)^{* * *}\end{array}$ & & \\
\hline Intl_own\% & & $\begin{array}{l}0.009 \\
(1.44)^{*}\end{array}$ & \\
\hline Pub_own\% & & $\begin{array}{l}0.021 \\
(3.79)^{* * *}\end{array}$ & \\
\hline State_own\% & & n.a. & \\
\hline Bank_own\% & & $\begin{array}{l}-0.000 \\
(-0.00)\end{array}$ & \\
\hline Empl_own\% & & $\begin{array}{l}0.057 \\
(1.38)^{*}\end{array}$ & \\
\hline Industry_own\% & & $\begin{array}{l}-0.004 \\
(-1.29)\end{array}$ & \\
\hline Pensfund_own\% & & $\begin{array}{l}-0.010 \\
(-1.06)\end{array}$ & \\
\hline Family_own\% & & $\begin{array}{l}-0.003 \\
(-1.02)\end{array}$ & \\
\hline Pub_maj & & & $\begin{array}{l}0.845 \\
(2.84)^{* * *}\end{array}$ \\
\hline Industry_maj & & & $\begin{array}{l}0.050 \\
(0.20) \\
\end{array}$ \\
\hline Pensfund_maj & & & $\begin{array}{l}-1.961 \\
(-1.76)^{* *}\end{array}$ \\
\hline Bank_maj & & & $\begin{array}{l}0.245 \\
(0.38) \\
\end{array}$ \\
\hline State_maj & & & n.a. (no observations) \\
\hline Empl_maj & & & n.a. (no observations) \\
\hline Family_maj & & & Default group \\
\hline Pseudo $\mathrm{R}^{2}$ & $5.12 \%$ & $6.92 \%$ & $6.13 \%$ \\
\hline$\chi^{2}$ & $28.79^{* * *}$ & $38.56^{* * *}$ & $34.30^{* * *}$ \\
\hline
\end{tabular}

${ }^{*} \mathrm{p}<.10,{ }^{* *} \mathrm{p}<.05,{ }^{* * *} \mathrm{p}<.01$ (2-tailed and 1-tailed for ownership variables). 
Table 3 Continued

Panel D: One or two large French auditors $(n=62)$ versus two small French auditors $(n=104)$

\begin{tabular}{|c|c|c|c|}
\hline & $\begin{array}{l}\text { Column (1) } \\
\text { Coefficient (z-value) }\end{array}$ & $\begin{array}{l}\text { Column (2) } \\
\text { Coefficient (z-value) }\end{array}$ & $\begin{array}{l}\text { Column (3) } \\
\text { Coefficient(z-value) }\end{array}$ \\
\hline Constant & $\begin{array}{l}-2.904 \\
(-2.77)^{* * * *}\end{array}$ & $\begin{array}{l}-3.732 \\
(-2.61)^{* * *}\end{array}$ & $\begin{array}{l}-3.470 \\
(-3.11)^{* * *}\end{array}$ \\
\hline Complex & $\begin{array}{l}0.279 \\
(1.14)\end{array}$ & $\begin{array}{l}0.262 \\
(1.02)\end{array}$ & $\begin{array}{l}0.236 \\
(0.94)\end{array}$ \\
\hline Ln(Assets) & $\begin{array}{l}0.214 \\
(2.40)^{* *}\end{array}$ & $\begin{array}{l}0.169 \\
(1.80)^{*}\end{array}$ & $\begin{array}{l}0.185 \\
(1.99)^{* *}\end{array}$ \\
\hline Leverage & $\begin{array}{l}-0.249 \\
(-0.35)\end{array}$ & $\begin{array}{l}-0.098 \\
-(-0.13)\end{array}$ & $\begin{array}{l}-0.198 \\
(-0.27)\end{array}$ \\
\hline Growth assets & $\begin{array}{l}0.002 \\
(0.82)\end{array}$ & $\begin{array}{l}0.002 \\
(0.79)\end{array}$ & $\begin{array}{l}0.001 \\
(0.65)\end{array}$ \\
\hline ROA & $\begin{array}{l}0.054 \\
(0.13)\end{array}$ & $\begin{array}{l}0.188 \\
(0.39)\end{array}$ & $\begin{array}{l}0.097 \\
(0.24)\end{array}$ \\
\hline Concentration & $\begin{array}{l}-0.408 \\
(-0.89)\end{array}$ & & \\
\hline Intl_own\% & & $\begin{array}{l}0.005 \\
(0.51)\end{array}$ & \\
\hline Pub_own\% & & $\begin{array}{l}-0.006 \\
(-0.64)\end{array}$ & \\
\hline State_own\% & & n.a. & \\
\hline Bank_own\% & & $\begin{array}{l}0.017 \\
(1.19)\end{array}$ & \\
\hline Empl_own\% & & $\begin{array}{l}0.094 \\
(1.23)\end{array}$ & \\
\hline Industry_own\% & & $\begin{array}{l}0.011 \\
(2.16)^{* *}\end{array}$ & \\
\hline Pensfund_own\% & & $\begin{array}{l}0.031 \\
(1.86)^{* *}\end{array}$ & \\
\hline Family_own\% & & $\begin{array}{l}-0.013 \\
(-2.53)^{* * * *}\end{array}$ & \\
\hline Pub_maj & & & $\begin{array}{l}0.769 \\
(1.44)^{*}\end{array}$ \\
\hline Industry_maj & & & $\begin{array}{l}1.151 \\
(2.67)^{* * *}\end{array}$ \\
\hline Pensfund_maj & & & $\begin{array}{l}2.789 \\
(2.40)^{* * *}\end{array}$ \\
\hline Bank_maj & & & $\begin{array}{l}1.283 \\
(1.28)^{*} \\
\end{array}$ \\
\hline State_maj & & & n.a. (no observations) \\
\hline Empl_maj & & & n.a. (no observations) \\
\hline Family_maj & & & Default group \\
\hline Pseudo ${ }^{2}$ & $4.34 \%$ & $11.25 \%$ & $9.70 \%$ \\
\hline$x^{2}$ & 9.53 & $24.68^{* *}$ & $21.29^{* *}$ \\
\hline
\end{tabular}

${ }^{*} \mathrm{p}<.10,{ }^{* *} \mathrm{p}<.05,{ }^{* * *} \mathrm{p}<.01$ (2-tailed and 1-tailed for ownership variables). 


\section{Table 3 Continued}

Variable definitions:

Complex: Sales/Lagged total assets

Ln(Assets): Natural log of total assets

Leverage: Total debt/Total assets

ROA: Return on assets

Growth assets: Percentage change in total assets

Concentration: Dummy variable, Concentration $=1$ if no shareholder owns more than $24.9 \%$, else 0 Intl_own\%: Percentage of shares owned by international investors

Pub_own\%: Percentage of shares owned by the general public

State_own\%: Percentage of shares owned by the state

Bank_own\%: Percentage of shares owned by banks

Empl_own\%: Percentage of shares owned by employees

Industry_own\%: Percentage of shares owned by the industry

Pensfund_own\%: Percentage of shares owned by pension funds

Family_own\%: Percentage of shares owned by families

Pub_maj: Dummy variable, Pub_maj $=1$ if largest ownership group is public, else 0

Industry_maj: Dummy variable, Industry_maj = 1 if largest ownership group is industry, else 0

Pensfund_maj: Dummy variable, Pensfund_maj $=1$ if largest ownership group is a pension fund, else 0

Bank_maj: Dummy variable, Bank_maj $=1$ if largest ownership group is bank, else 0

State_maj: Dummy variable, State_maj $=1$ if largest ownership group is state, else 0

Empl_maj: Dummy variable, Empl_maj = 1 if largest ownership group is employees, else 0

Family_maj: Dummy variable, Family_maj $=1$ if largest ownership group is family, else 0 
Table 4

OLS regression models of accruals

Panel A: Two Big 4 auditors versus all other auditor pairs

\begin{tabular}{|c|c|c|c|c|c|}
\hline & $\begin{array}{l}\mid \text { TACC } \mid \\
(n=271)\end{array}$ & $\begin{array}{l}|\mathbf{C A C C}| \\
(n=270)\end{array}$ & $\begin{array}{l}\text { AWCACC } \\
(n=261)\end{array}$ & $\begin{array}{l}\text { Income- } \\
\text { increasing } \\
\text { AWCACC } \\
(\mathrm{n}=123)\end{array}$ & $\begin{array}{l}\text { Income- } \\
\text { decreasing } \\
\text { AWCACC } \\
(\mathrm{n}=143)\end{array}$ \\
\hline & $\begin{array}{l}\text { Coefficient } \\
\text { (t-value) }\end{array}$ & $\begin{array}{l}\text { Coefficient } \\
\text { (t-value) }\end{array}$ & $\begin{array}{l}\text { Coefficient } \\
\text { (t-value) }\end{array}$ & $\begin{array}{l}\text { Coefficient } \\
\text { (t-value) }\end{array}$ & $\begin{array}{l}\text { Coefficient } \\
\text { (t-value) }\end{array}$ \\
\hline Constant & $\begin{array}{l}0.449 \\
(4.40)^{* * *}\end{array}$ & $\begin{array}{l}0.458 \\
(4.56)^{* * *}\end{array}$ & $\begin{array}{l}0.245 \\
(3.74)^{* * *}\end{array}$ & $\begin{array}{l}0.252 \\
(2.52)^{* *}\end{array}$ & $\begin{array}{l}-0.287 \\
(-2.05)^{* *}\end{array}$ \\
\hline Ln(Assets) & $\begin{array}{l}-0.019 \\
(-3.49)^{* * *}\end{array}$ & $\begin{array}{l}-0.019 \\
(-3.63)^{* * *}\end{array}$ & $\begin{array}{l}-0.013 \\
(-2.94)^{* * *}\end{array}$ & $\begin{array}{l}-0.014 \\
(-2.22)^{* *}\end{array}$ & $\begin{array}{l}0.014 \\
(2.06)^{* *}\end{array}$ \\
\hline Leverage & $\begin{array}{l}0.007 \\
(0.17)\end{array}$ & $\begin{array}{l}-0.001 \\
(-0.02)\end{array}$ & $\begin{array}{l}-0.000 \\
(-0.00)\end{array}$ & $\begin{array}{l}-0.028 \\
(-0.54)\end{array}$ & $\begin{array}{l}-0.013 \\
(-0.25)\end{array}$ \\
\hline ROA & $\begin{array}{l}-0.030 \\
(-0.40) \\
\end{array}$ & $\begin{array}{l}0.026 \\
(0.35) \\
\end{array}$ & $\begin{array}{l}-0.065 \\
(-0.98) \\
\end{array}$ & $\begin{array}{l}0.114 \\
(0.97) \\
\end{array}$ & \begin{tabular}{|l|}
0.140 \\
$(1.63)$ \\
\end{tabular} \\
\hline B4_B4 & $\begin{array}{l}-0.004 \\
(-0.14)\end{array}$ & $\begin{array}{l}-0.007 \\
(-0.23)\end{array}$ & $\begin{array}{l}-0.020 \\
(-0.71)\end{array}$ & $\begin{array}{l}-0.055 \\
(-1.47)^{*}\end{array}$ & $\begin{array}{l}-0.019 \\
(-0.46)\end{array}$ \\
\hline Adjusted $\mathrm{R}^{2}$ & $4.48 \%$ & $4.67 \%$ & $3.81 \%$ & $9.10 \%$ & $1.88 \%$ \\
\hline F-value & $2.27^{* *}$ & $2.32^{* *}$ & $2.03^{* * *}$ & $2.22^{* *}$ & 1.26 \\
\hline
\end{tabular}

${ }^{*} \mathrm{p}<.10,{ }^{* *} \mathrm{p}<.05,{ }^{* * *} \mathrm{p}<.01$ (2-tailed and 1-tailed for auditor combination). Industries dummies included in analysis but not reported.

Panel B: Two Big 4 auditors versus one Big 4 auditor paired with a non-Big 4 auditor

\begin{tabular}{|c|c|c|c|c|c|}
\hline & $\begin{array}{l}\mid \mathrm{TACC} \\
(\mathrm{n}=173)\end{array}$ & $\begin{array}{l}|\mathrm{CACC}| \\
(\mathrm{n}=172)\end{array}$ & $\begin{array}{l}\text { AWCACC } \\
(n=163)\end{array}$ & $\begin{array}{l}\text { Income- } \\
\text { increasing } \\
\text { AWCACC } \\
(\mathrm{n}=81)\end{array}$ & \begin{tabular}{|l|} 
Income- \\
decreasing \\
AWCACC \\
$(\mathrm{n}=82)$
\end{tabular} \\
\hline & \begin{tabular}{|l} 
Coefficient \\
(t-value)
\end{tabular} & $\begin{array}{l}\text { Coefficient } \\
\text { (t-value) }\end{array}$ & $\begin{array}{l}\text { Coefficient } \\
\text { (t-value) }\end{array}$ & $\begin{array}{l}\text { Coefficient } \\
\text { (t-value) }\end{array}$ & \begin{tabular}{|l|}
$\begin{array}{l}\text { Coefficient } \\
\text { (t-value) }\end{array}$ \\
\end{tabular} \\
\hline Constant & $\begin{array}{l}0.438 \\
(3.61)^{* * *}\end{array}$ & $\begin{array}{l}0.244 \\
(2.33)^{* *}\end{array}$ & $\begin{array}{l}0.390 \\
(3.94)^{* * *}\end{array}$ & $\begin{array}{l}0.332 \\
(3.51)^{* * *}\end{array}$ & $\begin{array}{l}-0.194 \\
(-0.95)\end{array}$ \\
\hline Ln(Assets) & $\begin{array}{l}-0.014 \\
(-2.06)^{* *}\end{array}$ & $\begin{array}{l}-0.015 \\
(-2.41)^{* *}\end{array}$ & $\begin{array}{l}-0.009 \\
(-1.62)\end{array}$ & $\begin{array}{l}-0.004 \\
(-0.78)\end{array}$ & $\begin{array}{l}0.017 \\
(1.67)^{*}\end{array}$ \\
\hline Leverage & \begin{tabular}{|l|}
-0.037 \\
$(-0.64)$ \\
\end{tabular} & $\begin{array}{l}-0.058 \\
(-1.05) \\
\end{array}$ & $\begin{array}{l}-0.045 \\
(-0.92) \\
\end{array}$ & $\begin{array}{l}-0.062 \\
(-1.12)\end{array}$ & $\begin{array}{l}0.049 \\
(0.55)\end{array}$ \\
\hline ROA & $\begin{array}{l}0.033 \\
(0.35)\end{array}$ & $\begin{array}{l}0.077 \\
(0.86)\end{array}$ & $\begin{array}{l}-0.091 \\
(-1.10)\end{array}$ & $\begin{array}{l}-0.036 \\
(-0.34)\end{array}$ & $\begin{array}{l}0.116 \\
(0.93)\end{array}$ \\
\hline B4_B4 & $\begin{array}{l}-0.016 \\
(-0.47)\end{array}$ & $\begin{array}{l}-0.016 \\
(-0.50)\end{array}$ & $\begin{array}{l}-0.019 \\
(-0.68)\end{array}$ & $\begin{array}{l}-0.044 \\
(-1.48)\end{array}$ & $\begin{array}{l}-0.16 \\
(-0.32)\end{array}$ \\
\hline Adjusted $\mathrm{R}^{2}$ & $7.00 \%$ & 8.1 & $5.22 \%$ & $15.48 \%$ & $2.3 \%$ \\
\hline F-value & $2.29^{* *}$ & $2.51^{* * *}$ & $1.89^{*}$ & $2.46^{* *}$ & 0.82 \\
\hline
\end{tabular}

${ }^{*} \mathrm{p}<.10,{ }^{* *} \mathrm{p}<.05,{ }^{* * *} \mathrm{p}<.01$ (2-tailed and 1-tailed for auditor combination). Industries dummies included in analysis but not reported. 
Table 4 Continued

Panel C: Big 4 and non-Big 4 auditor pair versus firms with two non-Big 4 auditors

\begin{tabular}{|c|c|c|c|c|c|}
\hline & $\begin{array}{l}|\mathbf{T A C C}| \\
(n=238)\end{array}$ & $\mid \begin{array}{l}|\mathbf{C A C C}| \\
(\mathrm{n}=237)\end{array}$ & $\begin{array}{l}\mid \text { AWCACC } \\
(\mathrm{n}=230)\end{array}$ & $\begin{array}{l}\text { Income- } \\
\text { increasing } \\
\text { AWCACC } \\
(\mathrm{n}=108)\end{array}$ & $\begin{array}{l}\text { Income- } \\
\text { decreasing } \\
\text { AWCACC } \\
(\mathrm{n}=96)\end{array}$ \\
\hline & $\begin{array}{l}\text { Coefficient } \\
\text { (t-value) }\end{array}$ & $\begin{array}{l}\text { Coefficient } \\
\text { (t-value) }\end{array}$ & \begin{tabular}{|l|} 
Coefficient \\
(t-value)
\end{tabular} & $\begin{array}{l}\text { Coefficient } \\
\text { (t-value) }\end{array}$ & $\begin{array}{l}\text { Coefficient } \\
\text { (t-value) }\end{array}$ \\
\hline Constant & $\begin{array}{l}0.393 \\
(4.56)^{* * *}\end{array}$ & $\begin{array}{l}0.372 \\
(4.39)^{* * *}\end{array}$ & $\begin{array}{l}0.257 \\
(3.42)^{* * *}\end{array}$ & $\begin{array}{l}0.318 \\
(2.74)^{* * *}\end{array}$ & $\begin{array}{l}-0.287 \\
(-1.89)^{*}\end{array}$ \\
\hline Ln(Assets) & $\begin{array}{l}-0.024 \\
(-3.79)\end{array}$ & $\begin{array}{l}-0.023 \\
(-3.79)^{* * *}\end{array}$ & $\begin{array}{l}-0.015 \\
(-2.76)^{* * *}\end{array}$ & $\begin{array}{l}-0.018 \\
(-2.43)^{* *}\end{array}$ & $\begin{array}{l}0.014 \\
(1.77)^{*}\end{array}$ \\
\hline Leverage & $\begin{array}{l}0.016 \\
(0.35)\end{array}$ & $\begin{array}{l}0.009 \\
(0.22)\end{array}$ & $\begin{array}{l}-0.003 \\
(-0.10) \\
\end{array}$ & $\begin{array}{l}-0.049 \\
(-0.82) \\
\end{array}$ & $\begin{array}{l}-0.007 \\
(-0.13) \\
\end{array}$ \\
\hline ROA & $\begin{array}{l}-0.010 \\
(-0.13)\end{array}$ & $\begin{array}{l}0.043 \\
(0.57)\end{array}$ & $\begin{array}{l}-0.058 \\
(-0.83)\end{array}$ & $\begin{array}{l}0.069 \\
(0.54)\end{array}$ & $\begin{array}{l}0.146 \\
(1.62)^{*}\end{array}$ \\
\hline B4_NB4 & $\begin{array}{l}0.013 \\
(0.56)\end{array}$ & \begin{tabular}{|l|}
0.004 \\
$(0.18)$
\end{tabular} & $\begin{array}{l}-0.008 \\
(-0.41)\end{array}$ & $\begin{array}{l}-0.046 \\
(-1.54)^{*}\end{array}$ & $\begin{array}{l}-0.022 \\
(-0.76)\end{array}$ \\
\hline Adjusted $\mathrm{R}^{2}$ & $5.53 \%$ & $5.12 \%$ & $2.28 \%$ & $9.84 \%$ & $0.79 \%$ \\
\hline F-value & $2.39^{* *}$ & $2.27^{* *}$ & 1.54 & $2.17^{* *}$ & 1.10 \\
\hline
\end{tabular}

${ }^{*} \mathrm{p}<.10,{ }^{* *} \mathrm{p}<.05,{ }^{* * *} \mathrm{p}<.01$ (2-tailed and 1-tailed for auditor combination). Industries dummies included in analysis but not reported.

Panel D: Large French auditors versus small French auditors

\begin{tabular}{|c|c|c|c|c|c|}
\hline & $\begin{array}{l}\mid \text { TACC } \mid \\
(n=94)\end{array}$ & $\begin{array}{l}|\mathbf{C A C C}| \\
(\mathrm{n}=94)\end{array}$ & $\begin{array}{l}\mid \text { AWCACC } \\
(\mathrm{n}=94)\end{array}$ & $\begin{array}{l}\text { Income- } \\
\text { increasing } \\
\text { AWCACC } \\
(\mathrm{n}=40)\end{array}$ & $\begin{array}{l}\text { Income- } \\
\text { decreasing } \\
\text { AWCACC } \\
(\mathrm{n}=54)\end{array}$ \\
\hline & $\begin{array}{l}\text { Coefficient } \\
\text { (t-value) }\end{array}$ & $\begin{array}{l}\text { Coefficient } \\
\text { (t-value) }\end{array}$ & $\begin{array}{l}\text { Coefficient } \\
\text { (t-value) }\end{array}$ & $\begin{array}{l}\text { Coefficient } \\
\text { (t-value) }\end{array}$ & $\begin{array}{l}\text { Coefficient } \\
\text { (t-value) }\end{array}$ \\
\hline Constant & $\begin{array}{l}0.389 \\
(2.99)^{* * *}\end{array}$ & $\begin{array}{l}0.388 \\
(2.76)^{* * *}\end{array}$ & $\begin{array}{l}0.363 \\
(2.99)^{* * *}\end{array}$ & $\begin{array}{l}0.559 \\
(2.25)^{* *}\end{array}$ & $\begin{array}{l}-0.160 \\
(-0.80)\end{array}$ \\
\hline Ln(Assets) & $\begin{array}{l}-0.030 \\
(-2.92)^{* * *}\end{array}$ & $\begin{array}{l}-0.031 \\
(-2.80)^{* * *}\end{array}$ & $\begin{array}{l}-0.026 \\
(-2.78)^{* * *}\end{array}$ & $\begin{array}{l}-0.043 \\
(-2.31)^{* *}\end{array}$ & $\begin{array}{l}0.008 \\
(0.67)\end{array}$ \\
\hline Leverage & $\begin{array}{l}0.057 \\
(0.88)\end{array}$ & $\begin{array}{l}0.052 \\
(0.75)\end{array}$ & $\begin{array}{l}0.041 \\
(0.69) \\
\end{array}$ & $\begin{array}{l}-0.018 \\
(-0.15)\end{array}$ & $\begin{array}{l}-0.062 \\
(-0.84)\end{array}$ \\
\hline ROA & $\begin{array}{l}-0.233 \\
(-1.73)\end{array}$ & $\begin{array}{l}-0.099 \\
(-0.68)\end{array}$ & $\begin{array}{l}-0.044 \\
(-0.35)\end{array}$ & $\begin{array}{l}0.142 \\
(0.37)\end{array}$ & $\begin{array}{l}0.259 \\
(1.98)^{*}\end{array}$ \\
\hline LF_NB4 & $\begin{array}{l}0.005 \\
(0.14)\end{array}$ & $\begin{array}{l}0.008 \\
(0.21)\end{array}$ & $\begin{array}{l}-0.014 \\
(-0.44)\end{array}$ & $\begin{array}{l}0.070 \\
(1.10)\end{array}$ & $\begin{array}{l}0.079 \\
(2.10)^{* *}\end{array}$ \\
\hline Adjusted $\mathrm{R}^{2}$ & $9.82 \%$ & $4.52 \%$ & $4.82 \%$ & $1.48 \%$ & $9.47 \%$ \\
\hline F-value & $2.01^{* *}$ & 1.44 & 1.47 & 0.94 & 1.55 \\
\hline
\end{tabular}

${ }^{*} \mathrm{p}<.10,{ }^{* *} \mathrm{p}<.05,{ }^{* * *} \mathrm{p}<.01$ (2-tailed and 1-tailed for auditor combination). Industries dummies included in analysis but not reported. 


\section{Table 4 Continued}

Variable definitions:

|TACC |: Absolute value of total accruals, scaled by lagged assets

|CACC | : Absolute value of current accruals, scaled by lagged assets

$\mid$ AWCACC |: Absolute value of abnormal working capital accruals, scaled by lagged assets

AWCACC: Abnormal working capital accruals, scaled by lagged assets

Ln(Assets): Natural log of total assets

Leverage: Total debt/Total assets

ROA: Return on assets

B4_B4: 2 Big 4 audit firms

B4_NB4: Big 4 audit firm and non-Big 4 audit firm

LF_NB4: Large French audit firm and a small non-Big 4 audit firm 
Table 5

OLS regression models of $P / B$ and $P / E$ ratios

Panel A: Two Big 4 auditors versus all other auditor pairs

\begin{tabular}{|l|l|l|}
\hline & $\begin{array}{l}\mathbf{P} / \mathbf{B} \\
(\mathbf{n}=339)\end{array}$ & $\begin{array}{l}\mathbf{P} / \mathbf{E} \\
(\mathbf{n}=324)\end{array}$ \\
\hline & $\begin{array}{l}\text { Coefficient } \\
\text { (t-value) }\end{array}$ & $\begin{array}{l}\text { Coefficient } \\
\text { (t-value) }\end{array}$ \\
\hline Constant & 2.023 & -7.514 \\
& $(2.38)$ & $(-1.24)$ \\
\hline Ln(Assets) & -0.007 & 1.527 \\
& $(-0.10)$ & $(2.96)^{* * *}$ \\
\hline Leverage & 0.0002 & -0.0006 \\
& $(2.29)^{* *}$ & $(-0.89)$ \\
\hline Sales Growth & 0.001 & 0.028 \\
& $(0.84)$ & $(2.73)^{* * *}$ \\
\hline B4_B4 & 0.081 & -0.881 \\
& $(0.18)$ & $(-0.27)$ \\
\hline Adjusted $\mathrm{R}^{2}$ & $1 \%$ & $3.92 \%$ \\
\hline F-value & 1.86 & $4.29^{* * *}$ \\
\hline & &
\end{tabular}

${ }^{*} \mathrm{p}<.10,{ }^{* *} \mathrm{p}<.05,{ }^{* * *} \mathrm{p}<.01$ (2-tailed)

Panel B: Two Big 4 auditors versus one Big 4 auditor paired with a non-Big 4 auditor

\begin{tabular}{|l|l|l|}
\hline & $\begin{array}{l}\mathbf{P} / \mathbf{B} \\
(\mathbf{n}=\mathbf{2 1 4})\end{array}$ & $\begin{array}{l}\mathbf{P} / \mathbf{E} \\
(\mathbf{n}=\mathbf{2 0 3})\end{array}$ \\
\hline & $\begin{array}{l}\text { Coefficient } \\
\text { (t-value) }\end{array}$ & $\begin{array}{l}\text { Coefficient } \\
\text { (t-value) }\end{array}$ \\
\hline Constant & 0.985 & -8.585 \\
& $(1.02)$ & $(-1.11)$ \\
\hline Ln(Assets) & 0.071 & 1.641 \\
& $(0.89)$ & $(2.54)^{* *}$ \\
\hline Leverage & 0.0004 & -0.0008 \\
& $(3.08)^{* * *}$ & $(-0.66)$ \\
\hline Sales Growth & 0.008 & 0.045 \\
& $(2.94)^{* * *}$ & $(3.03)^{* * *}$ \\
\hline B4_B4 & -0.009 & -1.062 \\
& $(-0.02)$ & $(-0.29)$ \\
\hline Adjusted $\mathrm{R}^{2}$ & $8.42^{*} \%$ & \\
\hline F-value & $4.81^{* * *}$ & $5.62 \%$ \\
\hline & & $4.01^{* * *}$ \\
\hline
\end{tabular}

${ }^{*} \mathrm{p}<.10,{ }^{* *} \mathrm{p}<.05,{ }^{* * *} \mathrm{p}<.01$ (2-tailed) 
Table 5 Continued

Panel C: Big 4 and non-Big 4 auditor pair versus firms with two non-Big 4 auditors

\begin{tabular}{|l|l|l|}
\hline & $\begin{array}{l}\mathbf{P} / \mathbf{B} \\
(\mathbf{n}=\mathbf{2 9 9})\end{array}$ & $\begin{array}{l}\mathbf{P} / \mathbf{E} \\
(\mathbf{n}=\mathbf{2 8 6})\end{array}$ \\
\hline & $\begin{array}{l}\text { Coefficient } \\
\text { (t-value) }\end{array}$ & $\begin{array}{l}\text { Coefficient } \\
(\mathrm{t}-\text { value })\end{array}$ \\
\hline Constant & 2.646 & -10.047 \\
& $(2.71)^{* * *}$ & $(-1.48)$ \\
\hline Ln(Assets) & -0.069 & 1.694 \\
& $(-0.84)$ & $(2.93)^{* * *}$ \\
\hline Leverage & 0.0002 & -0.0005 \\
& $(2.28)^{* *}$ & $(-0.77)$ \\
\hline Sales Growth & 0.001 & 0.028 \\
& $(0.79)$ & $(2.67)^{* * *}$ \\
\hline B4_NB4 & 0.129 & 1.078 \\
& $(0.39)$ & $(0.47)$ \\
\hline Adjusted $\mathrm{R}^{2}$ & $2.94 \%$ & $4.35 \%$ \\
\hline F-value & $2.22^{*}$ & $4.24^{* * *}$ \\
\hline
\end{tabular}

${ }^{*} \mathrm{p}<.10,{ }^{* *} \mathrm{p}<.05,{ }^{* * *} \mathrm{p}<.01$ (2-tailed)

\section{Panel D: Large French auditors versus small French auditors}

\begin{tabular}{|l|l|l|}
\hline & $\begin{array}{l}\mathbf{P} / \mathbf{B} \\
(\mathbf{n = 1 2 2})\end{array}$ & $\begin{array}{l}\mathbf{P} / \mathbf{E} \\
(\mathbf{n}=\mathbf{1 1 8})\end{array}$ \\
\hline & $\begin{array}{l}\text { Coefficient } \\
\text { (t-value) }\end{array}$ & $\begin{array}{l}\text { Coefficient } \\
\text { (t-value) }\end{array}$ \\
\hline Constant & 3.605 & -4.018 \\
& $(2.07)^{* *}$ & $(-0.38)$ \\
\hline Ln(Assets) & -1.460 & 1.151 \\
& $(-0.94)$ & $(1.22)$ \\
\hline Leverage & 0.000 & -0.0003 \\
& $(0.69)$ & $(-0.40)$ \\
\hline Sales Growth & -0.001 & 0.006 \\
& $(-0.79)$ & $(0.47)$ \\
\hline LF_NB4 & -0.020 & -0.119 \\
& $(-0.04)$ & $(-0.04)$ \\
& & \\
\hline Adjusted $\mathrm{R}^{2}$ & $-1.42 \%$ & -1.50 \\
\hline F-value & 0.58 & 0.57 \\
\hline
\end{tabular}

${ }^{*} \mathrm{p}<.10,{ }^{* *} \mathrm{p}<.05,{ }^{* * *} \mathrm{p}<.01$ (2-tailed)

Variable definitions:

P/B: Price Book ratio

$\mathrm{P} / \mathrm{E}$ : Price Earnings ratio

Ln(Assets): Natural log of total assets

Leverage: Total debt/Total assets

Sales Growth: Percentage change in sales over the past year

B4_B4: 2 Big 4 audit firms

B4_NB4: Big 4 audit firm and non-Big 4 audit firm

LF_NB4: Large French audit firm and a small non-Big 4 audit firm 